\title{
Chapter 8. The use of electroceuticals and neuromodulation in the treatment of migraine and other headaches
}

\author{
Sarah Miller MRCP and Manjit Matharu FRCP, PhD \\ Headache Group, Institute of Neurology, University College London and National Hospital for \\ Neurology and Neurosurgery, London, United Kingdom
}

Prepared For: Electroceuticals: Advances in Electrostimulation Therapies

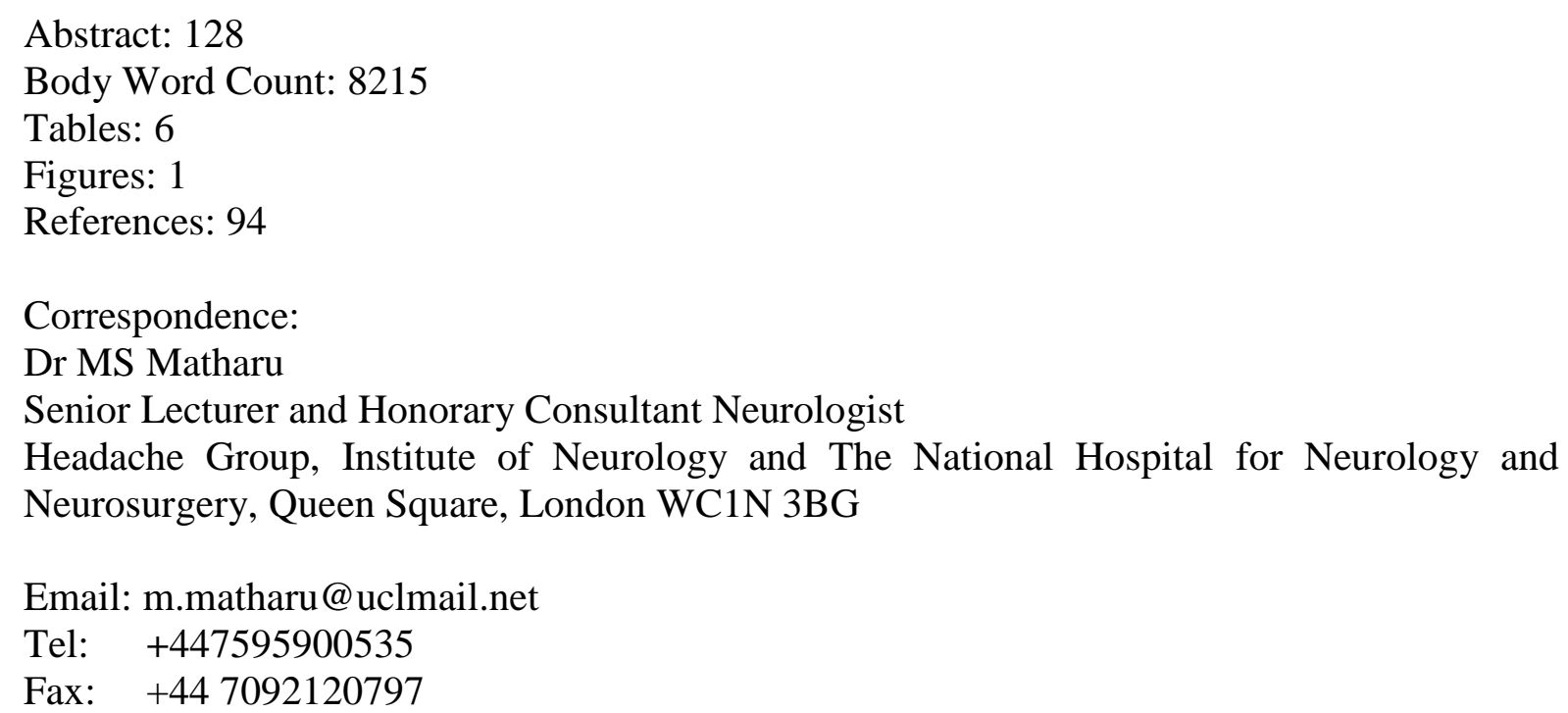




\begin{abstract}
H1 >
Over recent years there has been increasing interest in the role of neurostimulation in the treatment of headache disorders. Currently both peripheral and central neuromodulation devices are available although evidence to support their use is still limited. Both non-invasive and invasive devices can be used for neurostimulation. Non-invasive peripheral stimulation options include supra-orbital stimulation (Cefaly® device) and vagal nerve stimulation (gammaCore® device), while invasive peripheral stimulation options include occipital nerve stimulation and sphenopalatine ganglion stimulation. Non-invasive central neurostimulation option involves single pulse transcranial magnetic stimulation (SpringTMS® device), while invasive central neurostimulation can be carried out using ventral tegmental area deep brain stimulation. Neurostimulation therapies offer a promising approach to otherwise medically intractable or difficult to treat headache disorders with each device having specific roles within the treatment pathway.
\end{abstract}

\title{
INTRODUCTION <H1>
}

Primary headache conditions are benign, reoccurring headaches not caused by any underlying structural issue or disease. The primary headaches are subdivided into phenotypes based on the International Classification of Headache Disorders (ICHD-III beta).(1) The main divisions are migraine and the trigeminal autonomic cephalalgias (TACs). Migraine is a recurrent headache disorder manifesting in attacks of pain lasting between 4-72 hours, which is accompanied by nausea, vomiting, light and noise sensitivity and aggravation of the pain with movement. The TACs are a group of disorders characterised by unilateral head pain occurring in association with prominent ipsilateral cranial autonomic features. The TACs include cluster headache, paroxysmal hemicrania, hemicrania continua and short-lasting unilateral neuralgiform headache attacks, which is further subdivided into SUNCT (short-lasting unilateral neuralgiform headache attacks with conjunctival injection and tearing) and SUNA 
(short-lasting unilateral neuralgiform headache attacks with autonomic symptoms). The most common primary headache is migraine with an estimated $15 \%$ of the population affected.(2) The TACs are less common with estimated prevalence of cluster headache of 1 in 500 (3), of paroxysmal hemicrania around 0.5 per 1000 (4) and that of hemicrania continua and SUNCT/SUNA not well defined but thought to be similar to that of paroxysmal hemicrania.(4) The clinical features, epidemiology and first-line treatment options are summarised in Table 1. The above primary headache conditions can be classified by their frequency into either episodic or chronic forms. Chronic migraine is defined as a headache occurring on 15 or more days of the month (of which eight or more are migrainous) for a period of over three months. Chronic TACs are diagnosed when patients go a year without remission periods or with remission periods lasting less than one month.(1) Chronic headache is a global health issue affecting up to $4 \%$ of the population, (5) with chronic migraine or cluster headache forming the majority of chronic headaches seen in neurology units. The estimated prevalence of chronic migraine is $2 \%$ and chronic cluster headache $0.02 \%$.(6) Patients may have headaches that are chronic from onset or evolve from an episodic form.

Although advances in the management of headache disorders means that the majority can be managed with medical treatments, a significant minority will not tolerate or prove intractable to available preventative pharmacological treatments. Neurostimulation techniques with peripheral and central targets appear to offer a promising approach to treating such patients. Devices allowing acute treatment of attacks may be useful to those unable to use or who overuse acute medications such as triptans. The peripheral targets used include the occipital nerve, the supra-orbital nerves, the sphenopalatine ganglion and the vagus nerve. Current central targets are the ventral tegmental area and the cortex. In this chapter, the main focus is on the treatment of chronic migraine and chronic cluster headache as this is where the bulk of 
literature and experience lies. Some reference will be made to the treatment of episodic migraine and cluster headache where relevant.

\section{PATHOPHYSIOLOGY OF PRIMARY HEADACHE CONDITIONS $<$ H1 $>$}

\section{Migraine $<\mathbf{H 2}>$}

Migraine is a complex neurological disorder that affects multiple cortical, subcortical and brainstem regions that regulate the autonomic, affective, cognitive and sensory functions. The pathophysiology of the condition involves different neural networks and pathways interacting together to generate the clinical features of migraine. The main pathways and mechanisms involved in migraine generation include (Fig 1):

- the trigeminovascular system including the large intracranial vessels,

- brain hyperexcitability and cortical spreading depression (CSD),

- the trigeminocervical complex consisting of the caudal trigeminal nucleus and the spinal roots of $\mathrm{C} 1-\mathrm{C} 2$.

The innervation of large intracranial vessels and the dura comes from the first division of the trigeminal nerve, a pathway known as the trigeminovascular system.(7) Activation of trigeminal nerve endings results in the release of neuro-inflammatory peptides such as calcitonin gene regulating peptide (CGRP), substance $\mathrm{P}$ and nitric oxide. These inflammatory mediators result in the activation of trigeminal nerve endings on adjacent blood vessels and a positive feedback loop is established via trigeminal brainstem connections to higher centres resulting in pain generation.

Trigeminal afferents pass caudally through the trigeminal ganglion to synapse in the trigeminal-cervical complex. This complex provides an anatomical and functional overlap of trigeminal afferents and cervical afferents from the level of the trigeminal nucleus caudalis to the level of C2.(8) Stimulation of the cervical neurones at this level results in activation of 
trigeminal neurones, thus, nociceptive activation of either end of the pathway can result in both occipital and frontal pain. The trigeminal nucleus also makes connections with the thalamus via brainstem nuclei such as the periaqueductal gray, dorsal raphe nucleus and locus coeruleus.

There is evidence to support the concept that migraine sufferers have a sustained state of brain hyper-excitability.(9) Neurophysiological work shows increased visual evoked potentials and absence of habituation in migraineurs. Genetic causes of migraine have been linked to mutations leading to increased levels of synaptic glutamate, an excitatory neurotransmitter and transcranial magnetic stimulation studies has suggested reduced phosphene thresholds in migraineurs compatible with hyper-excitability. This excitability leads to a lowered threshold for the initiation of CSD. Cortical spreading depression, the physiological substrate of aura, consist of a wave of neuronal excitation spreading across the cortex followed by a reciprocal wave of neuronal inhibition.(10) Cortical spreading depression has been found to lead to the activation of the trigeminovascular system and potentially of brainstem regulatory centres, both of which can lead to pain generation.

\section{Trigeminal autonomic cephalalgias $<\mathrm{H} 2>$}

The pathophysiological constructs for TACs must account for the distinctive clinical characteristics of the disorders: the trigeminal distribution of pain, the ipsilateral autonomic features and the periodicity seen in cluster headache. Pain innervation of the head comes from branches of the first division of the trigeminal nerve. The links between the trigeminal system, the higher cervical nerve roots and brainstem structures are discussed above. The ipsilateral autonomic features are thought to arise from cranial parasympathetic activation and sympathetic hypofunctioning. The pathway controlling these symptoms is known as the trigeminoautonomic reflex. Experimental data suggests that stimulation of trigeminal afferents 
results in cranial autonomic outflow via this reflex.(11) In humans, the parasympathetic fibres involved in this reflex synapse in the sphenopalatine ganglion. Although the trigeminoautonomic reflex is active in other headache syndromes, it is the degree of activation in TACs that give the distinctive clinical features. Hypothalamic activation has been suggested on functional neuroimaging of TAC patients.(12-15) There is evidence of the role of hypothalamus in mediating anti-nociceptive and autonomic responses when intracranial pain structures are activated. In support of the role of the hypothalamus in pain processing in TACs, direct pathways between the hypothalamus and trigeminal nucleus have been mapped. Other supporting data for the importance of the hypothalamus in attack generation or pain control in TACs are the periodicity of cluster headache attacks that would suggest involvement of suprachiasmatic nucleus of the hypothalamus, where the "body clock" is sited, and the fact that hypothalamic peptides Orexin A and B elicit both pro- and anti-nociceptive effects on the trigeminal system.(16)

The current hypothesis is that TACs are due to a central abnormality in hypothalamic processing with subsequent activation of the trigeminovascular and trigeminoautonomic pathways via the superior salivatory nucleus, sphenopalatine ganglion and trigeminal pathways.

\section{PERIPHERAL NEUROSTIMULATION DEVICES<H1 >}

\section{Supraorbital nerve stimulation $\langle\mathbf{H} 2\rangle$}

The trigeminal system has a crucial role in generation of head pain. The supraorbital nerve is a branch of the frontal nerve (which in turn is a branch of the first division of the trigeminal nerve) and innervates the frontal sinus, upper eyelid and anterolateral part of the forehead and

scalp. A transcutaneous supraorbital nerve stimulator has been developed as a potential 
treatment for headache and case reports also exist on the potential use of subcutaneous supraorbital nerve stimulation in isolation or alongside occipital nerve stimulator devices.

\section{Evidence for the use of transcutaneous supraorbital nerve stimulation $<H 3\rangle$}

Transcutaneous supraorbital nerve stimulation involves the use of an external device to deliver an electrical current through the supraorbital nerves. The Cefaly® device is the only currently available external transcutaneous nerve stimulator. It is battery powered and worn on the forehead using a headband-like device. There is currently no evidence to support the use of transcutaneous nerve stimulation in chronic migraine or chronic cluster headache, either as an acute or preventative treatment. Some limited evidence of its possible use in episodic migraine is available.

\section{Acute treatment of episodic migraine $\langle H 4\rangle$}

No controlled evidence for the use of transcutaneous supraorbital nerve stimulation in the acute treatment of episodic migraine has been published. However, a single pilot study of the Cefaly ${ }^{\circledR}$ device, reported that use of the device was associated with pain freedom in only $13 \%$ of treated cases and actually had no effect in $57 \%$ of attacks.(17)

\section{Preventative treatment of episodic migraine $<H 4\rangle$}

The evidence for transcutaneous supraorbital nerve stimulation in preventative treatment of episodic migraine comes from a small sham-controlled study of the Cefaly® device and manufacturer's post-marketing survey data. $(18,19)$ The sham-controlled study of 67 patients with episodic migraine using either a sham or active supraorbital nerve stimulator device for three months reported a significant drop of $30 \%$ in migraine days in the active group compared to $4.9 \%$ in the sham group.(18) Responder rates for the device were comparable to traditional migraine preventative agents such as propranolol.(20) The post-marketing survey incorporated data from 2313 subjects who used the transcutaneous supraorbital nerve stimulator for migraine 
prevention. Fifty three percent of subjects rated themselves "satisfied" and continued treatment after a 40-day trial period.(19) Although the therapeutic gain in migraine day reduction was lower at $12 \%$ than that seen in other migraine preventatives such as topiramate $(25 \%)$, the lower levels of adverse events and higher rates of patient satisfaction with Cefaly® device may counterbalance this issue.

\section{Evidence for the use of subcutaneous supraorbital nerve stimulation $<H 3>$}

Subcutaneous supraorbital nerve stimulation is achieved by placing subdermal-subcutaenous electrodes on the forehead in the territory innervated by the supraorbital nerve.(21) The electrodes can be placed in isolation or in combination with occipital nerve electrodes. The only evidence for the use of subcutaneous supraorbital nerve stimulation comes from small open-label case series on the preventative treatment of chronic migraine and chronic cluster headache, most often in combination with occipital electrodes.

\section{Preventative treatment of chronic migraine $<H 4>$}

Two small series are available in the literature on the use of combined supraorbital and occipital nerve stimulation for the prevention of intractable chronic migraine. The first was by Reed et al. (22) and included seven patients receiving bilateral supraorbital and occipital electrodes. With a median follow-up of 15 months, all patients reported a more than $50 \%$ reduction in headache severity. Adverse events included lead migration, infection and allergy. Hann and Sharan performed a similar procedure on 14 patients.(23) With a mean follow-up of 31 months, ten patients had a more than $50 \%$ reduction in headache severity. Adverse events included lead migration, allodynia and infection and the group reported a reoperation rate of $36 \%$.

\section{Preventative treatment of chronic cluster headache $<H 4>$}

Current literature on subcutaneous supraorbital nerve stimulation for chronic cluster headache is limited to a total of six patients, one case report and one case series. Narouze and Kapural 
were the first to publish a case report of isolated supraorbital nerve stimulation for chronic cluster headache in 2007.(24) Following the implant of a unilateral lead with programmes for both preventative and acute treatments, the patient had a complete remission of pain for over 14 months. When the stimulation was terminated, the attacks returned within 24 hours. Interestingly, the device was also successfully used as an abortive treatment to terminate acute attacks. The second series of four chronic cluster headache patients with a mixture of unilateral and bilateral leads reported a more than $50 \%$ reduction in pain severity in all patients after a follow-up of 25 months.(25) Adverse events were high with two patients suffering electrode erosion through the skin and one a lead infection.

\section{Safety of supraorbital nerve stimulation $\langle\mathrm{H} 3\rangle$}

Transcutaneous supraorbital nerve stimulation appears to be a safe and well-tolerated treatment option. In the study from Magis et al. of 2313 participants using the Cefaly® device for the treatment of migraine only $4 \%$ of subjects reported any adverse events.(19) The most frequent adverse event was intolerable paraesthesia (30\% of adverse events) but sleepiness during treatment $(12 \%)$, skin irritation at the application site $(5 \%)$ and worsening of headache with treatment $(12 \%)$ were also reported.

Subcutaneous supraorbital nerve stimulation seems to have a similar risk profile to ONS. As the majority of patients reported in literature had both ONS and supraorbital electrodes, the adverse event data is discussed in ONS section.

\section{The possible role of supraorbital nerve stimulation $<H 3>$ (Table 2)}

Transcutaneous supraorbital stimulation may be useful in the prevention of episodic migraine in those unable to tolerate or not responding to traditional pharmacotherapy. As yet, there is not enough evidence to support its use for chronic migraine, chronic cluster headache or acute treatment of either migrainous or cluster attacks. From the limited evidence available for 
invasive supraorbital nerve stimulation, routine use of this procedure to treatment primary headaches cannot be advocated as yet

\section{Vagal nerve stimulation $\langle\mathrm{H} 2\rangle$}

The vagus nerve contains both motor and sensory components and has a role in controlling autonomic responses as well as pain processing via its projections to higher pain control centres. The initial concept of vagal nerve stimulation as a headache treatment came following observations of migraine improvement in patients undergoing invasive vagal nerve stimulator implants for intractable epilepsy.(26) The use of invasive vagal nerve stimulation for headache has been limited to small case reports. The development of non-invasive transcutaneous vagal nerve stimulator devices such as the gammaCore ${ }^{\circledR}$, a handheld device used on the neck, has led to a resurgence of interest in the role of vagal nerve modulation in primary headache.

\section{Evidence for the use of transcutaneous vagal nerve stimulation $\langle$ H3 $>$}

\section{Preventative treatment of chronic cluster headache $<H 4>$}

Available evidence for the possible use of transcutaneous vagal nerve stimulation comes from a study of the gammaCore ${ }^{\circledR}$ device, the Prevention and Acute Treatment of Chronic Cluster Headache (PREVA) trial.(27) This trial, consisting of 45 active and 47 control subjects, compared standard of care plus vagal nerve stimulation to standard care alone. Regular use of the gammaCore ${ }^{\circledR}$ device for four weeks was associated with a significant reduction in cluster attack frequency compared to control (6 vs. 2 less attacks a week). The 50\% response rate was also higher in the active group (40\% vs. $8 \%$ ). Following a four-week extension phase, both the reduction in attack frequency and response rate were seen to increase (to 8 attacks a week less and a $46 \%$ responder rate) suggesting a prolonged period of use is required to gain maximal benefit. Following treatment, 50\% reported satisfaction with the device and $65 \%$ would recommend treatment to others. 
A small open-label series of 19 patients using the gammaCore ${ }^{\circledR}$ device reported that it was useful as an acute treatment with $47 \%$ of attacks terminated within 11 minutes.(28) Subsequently, the PREVA study also reported on the use of the gammaCore® device to abort cluster attacks.(27) The use of transcutaneous vagal nerve stimulation as an acute treatment in 75 of 92 participants had no effect on cluster headache attack duration or severity. The PREVA study results suggest that there is no role for the use of gammaCore ${ }^{\circledR}$ as an acute treatment in cluster headache.

\section{Preventative treatment of chronic migraine $<H 4>$}

The controlled trial evidence for the use of transcutaneous vagal nerve stimulation with the gammaCore ${ }^{\circledR}$ as a preventative treatment in chronic migraine is limited to a single trial of 59 patients.(29) The trial, comparing two months treatment with active treatment to treatment with a sham device, failed to show a difference in headache day reduction between the groups (reduction of 2 days per group). An open-label extension phase suggested a significant difference emerges with a longer duration of treatment but further studies are needed to validate this.(30)

\section{Acute treatment of migraine $<H 4>$}

There is no controlled data to support the use of transcutaneous vagal nerve stimulation with the gammaCore ${ }^{\circledR}$ device in the acute treatment of migraine. Open-label data is, however, available on a total of 27 patients with episodic migraine (31) and 48 with high frequency or chronic migraine.(32) In the episodic migraine cohort, a total of 80 attacks were treated and $22 \%$ of attacks achieved pain freedom within two hours, a figure similar to that seen with Naproxen 500mg but below the $67 \%$ reported with Sumatriptan100mg. $(31,33,34)$ The series of high frequency and chronic migraine reported by Barbanti et al. (32) included 131 attacks treated over a 2-week period. In this cohort, $23 \%$ were pain free at two hours. 


\section{Evidence for the use of invasive vagal nerve stimulation $\langle H 3\rangle$}

Invasive vagal nerve stimulation is carried out primarily for intractable epilepsy and involves the implantation of an electrode over the left vagus nerve.(35) Following reports of pain relief in concurrent migraine attacks, some groups have used the implants for the treatment of intractable chronic migraine.

\section{Preventative treatment of chronic migraine $<H 4>$}

The outcomes of invasive vagal nerve stimulation in chronic migraine are limited to three series.(36-38) Mauskop reported on four patients treated with invasive vagal nerve stimulation, two of whom achieved substantial improvements.(36) Hord et al. found four patients with migraine within their cohort of 27 epilepsy patients undergoing invasive vagal nerve stimulation. All reported a decrease in migraine intensity and frequency, with one being rendered pain free.(38) The final series by Cecchini and colleagues (2009) reported on four patients implanted for chronic migraine with two reporting a more than $50 \%$ reduction in headache frequency.

\section{Safety of vagal nerve stimulation $<H 3>$}

Transcutaneous vagal nerve stimulation appears to be a safe treatment with no serious adverse events linked to the device recorded. Using data from the above studies, $(27,31)$ the most common adverse events reported were facial muscle twitching, neck pain, rash or redness at the application site and worsening of the headache. In sham-controlled studies, $(27,29)$ it was noted that similar proportions of active and control subjects reported adverse events and in fact, control subjects in the Silberstein et al. study (29) on chronic migraine prevention reported more adverse events of severe intensity than those in the active group. 


\section{The possible role of vagal nerve stimulation $<H 3>$ (Table 2)}

Available literature on transcutaneous vagal nerve stimulation using the gammaCore ${ }^{\circledR}$ device suggests that at present, it could be considered for the use of prevention of chronic cluster headache. There is, as yet, insufficient evidence for the use of transcutaneous vagal nerve stimulation for acute or preventative treatment of migraine and the acute treatment of cluster headache. From current evidence, there is not a role for invasive vagal nerve stimulation in the treatment of primary headaches.

\section{Occipital nerve stimulation $\langle\mathbf{H} 2\rangle$}

The occipital region is innervated by the greater, lesser and least occipital nerves. The greater occipital nerve is a branch of the $\mathrm{C} 2$ spinal root and provides innervation to the occipito-parietal area around 6-8 $\mathrm{cm}$ wide ascending paramedially from the suboccipital region to the vertex.(39) There is an anatomical overlap between the cervical and trigeminal afferents from the level of the trigeminal nucleus caudalis to the level of C2.(8) This overlap allows the stimulation of the occipital region to modulate pain in both trigeminal and cervical distributions. Occipital nerve stimulation (ONS) involves a non-destructive surgical process whereby electrodes are placed subcutaneously in the occipital region at the level of $\mathrm{C} 1$ and then wired to an implantable pulse generator (IPG) in the chest, abdomen or occasionally buttocks. Current batteries are rechargeable with a lifespan close to 10 years. Patients are able to adjust their own stimulation intensity levels using a hand-held remote control. Stimulation parameters of frequency, pulse width and voltage are adjusted to achieve continuous comfortable paraesthesia in the distribution of the greater occipital nerves. The optimum settings for ONS are not yet defined and there is a wide variation in the stimulation settings used across centres. 


\section{Evidence for the use of occipital nerve stimulation $\langle$ H3>}

ONS is most commonly used for chronic cluster and chronic migraine and so more extensive literature exists to support its use in these conditions. As with other neurostimulation techniques, the majority of published data on the use of ONS for primary headaches consists of open-label case series. However, randomised placebo-controlled trials have been conducted on the use of ONS in the prevention of chronic migraine. Smaller open-label series exist for the use of ONS in SUNCT/SUNA and hemicrania continua. Table 3 summarises the available published case studies on ONS in primary headache. It is worth stressing the fact that there is no data to support the use of ONS in the acute treatment of any primary headache syndromes.

\section{Preventative treatment of chronic migraine $\langle H 4>$}

The outcomes of the three randomised placebo-controlled trials on ONS in chronic migraine have been somewhat mixed. The first trial conducted in 2009, the Precision Implantable Stimulator for Migraine (PRISM) study, reported on the outcomes of 125 subjects randomised to active or sham stimulation for three months.(40) Although full results are not yet available, preliminary data failed to show a significant reduction in migraine days between treatment groups. The second trial, the occipital nerve stimulation for the treatment of intractable chronic migraine headache (ONSTIM) study, published in 2011, was a randomised controlled study of 61 subjects comparing active adjustable stimulation (28 patients), pre-set "sham" stimulation (16 patients) and standard medical treatment (17 patients).(41) A positive clinical response (defined as a $50 \%$ reduction in headache days or greater than 3-point reduction in pain scores) was seen in $39 \%$ of the active adjustable stimulation group, $6 \%$ in the sham-stimulation group and $0 \%$ in the medical group. The most recent study from Silberstein et al. published in 2012 reported on 157 patients comparing active stimulation (105 patients) to sham stimulation (52 subjects).(42) The primary outcome measure of clinical responders (the proportion of patients achieving a $50 \%$ or more reduction in pain scores) showed no significant difference between 
groups (17\% vs. 14\%). However, significant differences between the groups were seen in the reduction of headache days ( $27 \%$ vs. $15 \%)$ and in the proportion of patients achieving a $30 \%$ or more reduction in pain scores (38\% vs. $19 \%)$. As the International Headache Society have issued clinical trial guidelines stating that, due to the intractable and highly disabling nature of chronic migraine, a $30 \%$ reduction in outcome measures should be considered as clinically relevant,(43) these findings can be interpreted as a positive outcome of ONS for chronic migraine. A meta-analysis of the pooled data has found that ONS was associated with a reduction of 3 migraine days per month after three months of active treatment when compared to sham stimulation.(44) Interestingly, comments are made in the same systemic review that the poor and incomplete reporting of data has hindered greater interpretation of results. Openlabel data on ONS in chronic migraine is summarised in Table 3 (45) and adverse event data that has been a cause for concern in some ONS series in Table 4.

\section{Preventative treatment of chronic cluster headache $\langle H 4\rangle$}

Although as of yet controlled data on the use of ONS in chronic cluster headache is not available, the available open-label data supports the potential efficacy of the treatment (Table 3).(46) Over 90 patients have been reported in the literature and a pooled analysis suggests a mean reduction of daily attack frequency of 67\%.(47) Numerous case series have been published (Table 3) and we will discuss some of the larger ones in more detail below. Individual case reports will not be explored.

The first published cohort of ONS in chronic cluster headache was in 2007 and involved the prospective study of eight patients treated with unilateral ONS lead implantation ipsilateral to the side of pain.(48) After a mean follow-up period of 15 months, five patients were considered to be clinical responders with a reduction of more than $50 \%$ in daily attack frequency. In fact, all of these patients reported a more than $90 \%$ reduction in attack frequency and two remained pain-free for prolonged periods. There was a delay of at least two months following implant 
before clinical response emerged and attacks recurred or worsened within days to weeks of stimulation stopping - a feature that has been consistently reported in studies of ONS for primary headaches ever since. The group also reported that two patients with initial relief of their cluster attacks went on to develop new attacks on the opposite side to the ONS electrode. This phenomenon has been confirmed by other series and has led to recommendations that bilateral leads are placed in all patients. Although no serious adverse events were reported, lead migration and electrode displacement were observed (Table 4).

Burns et al. reported on a cohort of 14 medically intractable chronic cluster headache patients undergoing bilateral ONS implants. $(49,50)$ Following a median follow-up period of 18 months, ten of the 14 patients reported an improvement. Of those with benefit, three had a more than $90 \%$ reduction in attack frequency and a further three had a reduction of between 40 and $60 \%$. As in the previous series by Magis et al.(48), a delay of weeks was seen until clinical response and attacks were seen to return within days when the devices were turned off. Adverse events reported included lead migration in nearly a third of patients, superficial infection, painful paraesthesia and neck stiffness (Table 4).

In 2011, Fontaine and colleagues reported on their cohort of 13 chronic cluster headache patients undergoing ONS.(51) After a mean follow-up period of 15 months, a reduction of $68 \%$ was seen in mean attack frequency and a $50 \%$ improvement in attack frequency was seen in ten of the patients.

Magis et al. have examined long-term efficacy in their cohort with a mean follow-up time of 37 months.(52) Of the 15 patients implanted, 14 went on to long-term follow-up (one implant was removed due to infection). Eleven of the 14 patients reported a more than $90 \%$ reduction in attack frequency. Again, the authors commented on side shifting of attacks when unilateral stimulation was employed and adverse events were similar to their previous report. Other 
groups looking at long-term outcome have also reported sustained efficacy over periods of 2033 months but patient numbers were very small; three in the series by Schwedt et al. and five in the series from Brewer et al. $(53,54)$.

\section{Preventative treatment of other TACs $<H 4>$}

Published data on the use of ONS in SUNCT/SUNA is currently limited to a series of nine patients with median follow-up of 38 months.(55) Authors report that four patients became pain free following treatment and all others had a more than $80 \%$ improvement in attack frequency. As with ONS in chronic cluster headache, a time lag to clinical response was observed as was worsening of attacks within days to weeks of stimulation stopping. A total of ten patients with hemicrania continua treated with ONS in an open-label fashion are currently reported in the literature.(53, 54, 56, 57) All were treated with unilateral miniaturised stimulation devices no longer available for use. Although outcome measures differ across the four cohorts, it appears that at least five were counted as clinical responders (Table 3). There are no reports on the use of ONS in paroxysmal hemicrania as yet available in the literature.

\section{Safety of occipital nerve stimulation $<$ H3> (Table 4)}

Major concerns have been voiced over the adverse event data collected from the controlled and open-label studies of ONS in primary headache, particularly hardware related events. Adverse event data available in the literature is summarised in Table 4.(58-63) Lead migration was reported in $24 \%$ of ONSTIM subjects,(41) $7 \%$ in the PRISM series (40) and in up to $19 \%$ of subjects in the extended phase of the Silberstein et al. cohort. (64) Open-label series has reported lead migration rates between $4-53 \%$ with the series from Brewer et al. reporting the need for lead revision in 58\% of patients. A high rate of infection has also been reported in a

number of series ranging from 4-29\%. Many of the complications reported in the ONS 
literature are potentially serious and often require surgical intervention. However, data is emerging that adverse event rates can be dramatically reduced if ONS implants are conducted by well-trained, highly experienced surgical teams specialising in ONS surgery. A review of the adverse event data collected from the randomised study of Silberstein et al. showed that the incidence of surgery-related adverse events and the need for additional surgical procedures decreased with increased levels of surgical experience. (65)

\section{The possible role of occipital nerve stimulation $<\mathrm{H3}>$ (Table 2)}

As with all invasive neuromodulation treatments, ONS should be reserved for those with highly intractable medical refractory guidelines that have failed to respond to all other treatments. To stress this point, the European Headache Society has published clear guidelines on the use of invasive neurostimulation and this is summarised in Table 5. From current data, ONS could be considered for the preventative treatment of refractory chronic migraine and cluster headaches (and possibly other TACs) once they have failed all available pharmacological input. In order to minimise adverse events, patients should be assessed and treated in highly specialised units.

\section{Sphenopalatine ganglion stimulation $<\mathbf{H 2}>$}

The sphenopalatine ganglion (SPG) is an extracranial structure lying in the pterygopalatine fossa (PPF) containing both sympathetic and parasympathetic fibres. The SPG has connections, both direct and indirect, to many centres considered important in nociception and the pathophysiology of cluster headache such as the trigeminovascular system, the superior salivatory nucleus and the hypothalamus. Given the anatomy of the SPG, it has been investigated as a potential target in the treatment of cluster headache. Sphenopalatine ganglion stimulation can be achieved using a Pulsante ${ }^{\circledR}$ device, which has controlled evidence for 
efficacy in chronic cluster headache. The Pulsante® device is a miniaturised implantable neurostimulator with integral lead and battery. The lead is placed within the PPF using minimally invasive surgery with a trans-oral approach and the patient then controls the device using a handheld remote control.

\section{Evidence for the use of sphenopalatine ganglion stimulation $\langle H 3\rangle$}

Sphenopalatine ganglion stimulation has been developed for use in chronic cluster headache. Evidence is limited to one randomised control study although further studies are currently ongoing.

\section{Acute treatment of chronic cluster headache $<H 4>$}

A randomised sham-controlled trial of 28 patients used the Pulsante ${ }^{\circledR}$ device to treat acute cluster attacks with either full, sub-perception or sham stimulation levels.(66) Pain relief after 15 minutes of SPG stimulation was seen in a significantly higher number of full-stimulation treated attacks (67\%) than either sub-perception level (7\%) or sham stimulation (7\%). After two months of treating acute attacks, only $31 \%$ of the full-stimulation group were still using medication to abort attacks compared to $77 \%$ in the sham stimulation group.

\section{Preventative treatment of chronic cluster headache $\langle H 4\rangle$}

During the above controlled trial, it was observed that subjects using the Pulsante ${ }^{\circledR}$ device began to report a reduction in attack frequency over time. After the two month study period, $43 \%$ of subjects using the full-stimulation device to treat attacks regularly reported a more than

$50 \%$ reduction in daily attack frequency suggesting that the device has a preventative effect.(66) Further study into the efficacy and optimal stimulation settings of SPG stimulation as a preventative treatment for chronic cluster headache is ongoing. 


\section{Safety of sphenopalatine ganglion stimulation $\langle\mathrm{H3}\rangle$}

In the available study, $81 \%$ of subjects reported a transient sensory disturbance within the maxillary nerve distribution post-operatively but this resolved within three months in the majority of cases.(66) Two patients reported lead migration and misplacement requiring surgical revision and one a post-operative infection requiring antibiotics.

\section{The possible role of sphenopalatine ganglion stimulation $<\mathrm{H3}>($ Table 2)}

Guidelines for the use of SPG stimulation in chronic cluster headache were published by a group of headache experts in 2014.(67) At present, the treatment should be considered as an acute treatment, with potential additional preventative effects, in those with medically intractable chronic cluster headache who have failed all available pharmacological therapies. The Pulsante ${ }^{\circledR}$ device may be particularly useful for those with contraindications to Sumatriptan or in those with a high frequency of daily attacks.

\section{CENTRAL NEUROSTIMULATION DEVICES $<$ H1 $>$}

\section{Deep brain stimulation of the ventral tegmental area $<\mathrm{H} 2>$}

Functional neuroimaging studies on primary headache conditions have suggested that during acute cluster attacks there are changes in the posterior hypothalamic region in TACs that are not present in migraine. $(12-15,68)$ Further work has shown that stimulation of the same area in cluster headache patients increases blood flow throughout areas of the central pain matrix.(69) In 2001, Leone et al. used this functional imaging data evidence to implant deep brain electrodes in what was described as the posterior hypothalamic region in a patient with highly refractory chronic cluster headache.(70) Detailed analysis of the anatomy of the region described in the literature and on imaging has suggested that the actual site of interest for deep brain stimulation (DBS) is the ventral tegmental area and not the posterior hypothalamus.(71) Stereotactic surgical techniques are used to place an electrode within the target area ipsilateral 
to the side of headache. The device is kept active at all times and patients have limited control over the settings.

\section{Evidence for the use of ventral tegmental area deep brain stimulation $<H 3\rangle$}

On the basis of the above functional neuroimaging studies, DBS is considered a possible treatment for TACs and not migraine. Although there are now a number of open-label studies on the use of DBS for chronic cluster headache (Table 6) there is only one placebo-controlled trial available in the literature that, unfortunately, had deeply-flawed study design.(72) Given the rarity of the TACs and the invasive nature of DBS surgery, it is highly unlikely that high quality controlled studies will ever be conducted in this area. Deep brain stimulation has been proven ineffective in the acute treatment of cluster attacks.(73)

\section{Preventative treatment of chronic cluster headache $\langle H 4\rangle$}

There are now over 50 patients with DBS for chronic cluster headache published in the literature with an overall response rate (50\% reduction in attack frequency or pain score) of $71 \%$ (Table 6). A summary of the available open-label series is given in Table $6(72,74-79)$ and the largest of these series are examined further below.

Schoenen et al. implanted DBS leads into six patients with chronic cluster headache.(76) After a mean follow-up of 14.5 months in four of the patients, two patients were pain free, one was having less than three attacks a month and one reported no effect. One patient selected for treatment did not undergo implant due to a severe anxiety attack suffered during the operation. The only fatal adverse event recorded with DBS for headache occurred in this series with a patient dying post-operatively due to an intracerebral bleed along the lead. This tragic outcome led to a review of the use of DBS and guidelines that stress that DBS should be considered only as a last resort in patients with no other treatment options.(80) Bartsch et al. (74)published a series of six patients in 2008 with a follow-up of up to 17 months. At follow-up, three patients 
were almost pain free but one further patient who originally reported a more than $90 \%$ improvement in attack frequency lost efficacy over time so that after three months they nolonger reported any benefit. In 2011, both Franzini et al. (77) and Seijo et al.(78) each published a series of six patients undergoing DBS for chronic cluster headache. In the cohort from Franzini, five patients were reported as being pain free after up to 22 months follow-up. In the Seijo series, all patients reported a more than $50 \%$ reduction in attack frequency after mean follow-up of 33 months with two being pain free. This series commented on a number of clinically relevant observations such as the occurrence of a transient benefit or "stun period" for up to two weeks following implantation, a feature of the treatment that our group sees commonly but which is not widely discussed in the literature. Again, a delay of weeks to months was observed before clinical benefit was observed and attacks were noted to return within days to weeks when stimulation was stopped. In terms of adverse events, the group reports the most common complaints were of transient diplopia and dizziness related to changes in stimulation parameters.

The largest open-label series of 16 patients in 2013 is also that with the longest follow-up period. Leone et al.(79) reported that following a median follow-up of nine years, six remained pain free and a further six had converted to episodic cluster headache. In five of the pain free patients, the stimulator had been switched off with long-term remission maintained. Adverse events in the cohort included a post-operative seizure, infection (in four patients), electrode displacement (in two patients) and a non-symptomatic intraventricular haemorrhage was seen in one patient.

Fontaine et al. performed a randomised sham-controlled crossover study on DBS for chronic cluster headache in 2010.(72) In this study, 11 patients were enrolled to a protocol consisting of two crossover periods of either sham or active stimulation each lasting one month in duration followed by a one-year open-label extension period. There was no difference in attack 
frequency between active and sham groups at the end of the two months crossover period. However, by the end of the longer open-label phase, more than $50 \%$ of subjects reported a more than 50\% reduction in attack frequency. The negative outcome of the randomised part of the study is now considered to be due to poor study design with the cross-over periods far too short to account for the consistent delay to response seen in the open-label studies. Adverse events in this cohort included infection of the system requiring removal of the hardware in one patient.

\section{Preventative treatment of SUNCT/SUNA<H4>}

The only other literature currently available on the use of ventral tegmental area DBS involve cases of SUNCT/SUNA. In total there are three case reports (81-83) and a series of six patients with refractory SUNCT/SUNA treated with DBS.(84) All three case reports were of successful treatment with all reporting a more than $90 \%$ improvement in attack frequency. In the case series, attack frequency reduced by a median of $79 \%$ and five out of six patients were considered clinical responders (Table 6). These data need to be interpreted with caution as the numbers reported are small and there is likely to be reporting bias.

\section{Safety of ventral tegmental area deep brain stimulation $<H 3>$}

The death of a patient in the Schoenen et al. cohort from an intracerebral haemorrhage has led to concerns regards the safety of DBS in headache.(76) Other reported adverse events include non-symptomatic intraventricular haemorrhage, infection sometimes necessitating removal of the DBS system and electrode displacement. Adverse events from available cohorts are summarised in Table 6. Due to the potential serious adverse events, guidelines for DBS patient selection have been produced emphasising that surgery should be offered as a last resort only in patients with TACs who have failed all other available treatments (Table 5).(80) 


\section{The possible role of ventral tegmental area deep brain stimulation $<H 3>$ (Table 2)}

On the basis of currently available evidence, DBS should be considered for medically intractable chronic cluster headache (and potentially other TACs) that have proven resistant to all other treatments, including other forms of neurostimulation. Due to the risks of surgery, implants should only be undertaken in highly specialised units and guidelines state that patients should be managed by a multidisciplinary team including psychologists.(80)

\section{Transcranial magnetic stimulation $<\mathbf{H 2}>$}

It has been proposed that patients with migraine have a state of abnormal brain hyperexcitability and this theory is supported by transcranial magnetic stimulation studies.(7, 9). This hyperexcitable cortex is proposed to have a lower threshold for activation of cortical spreading depression (CSD), a process linked to the generation of migraine aura and activation of meningeal and trigeminal nociceptors.(10) Transcranial magnetic stimulation has been shown in animal studies to inhibit CSD and reduce cortical hyperexcitability by modulating levels of dopamine and glutamate.(9) On the basis of animal studies, transcranial magnetic stimulation was investigated as a potential treatment for migraine with aura. The SpringTMS $®$ device, a single-pulse transcranial magnetic stimulator was designed specifically for migraine treatment. The device applies a brief single magnetic pulse to the scalp and underlying cortex resulting in induced electrical field generation in the cortex, changes in neurotransmitter release and disturbance of CSD.

Acute treatment of episodic migraine with and without aura $<H 4>$

The evidence for the use of the SpringTMS $®$ device in acute migraine comes from a small sham-controlled study and post-marketing surveys. The sham-controlled study involved 164 migraine with aura patients using the device as an acute treatment for migraine attacks.(85) Active treatment was associated with a significantly higher rate of pain-freedom than sham 
treatment at both two hours (39\% vs. $22 \%)$ and twenty-four hours $(29 \%$ vs. $16 \%)$. The therapeutic gain of transcranial magnetic stimulation for acute migraine treatment was calculated at $17 \%$. An open-label post-marketing survey included data on the acute treatment of migraine with and without aura in 190 patients who used the device for three months.(86) At the end of follow-up, 105 patients had discontinued the treatment mainly due to lack of efficacy, cost or convenience. Of those completing the follow-up period, $62 \%$ were noted as reporting "some" reduction in migraine intensity and 59\% "some" reduction in migraine duration.

Preventative treatment of episodic or chronic migraine $\langle H 4\rangle$

On the basis of currently available data, there is insufficient evidence to support the use of the SpringTMS $®$ device in the preventative treatment of migraine.

\section{Safety of transcranial magnetic stimulation $<H 3>$}

A safety review of published literature on the use of transcranial magnetic stimulation for migraine shows that the treatment is low-risk and well tolerated.(87) The most commonly reported adverse events in the transcranial magnetic stimulator literature include dizziness and drowsiness during treatment. In the sham-controlled trial from Lipton et al.,(85), prevalence of adverse events was low (14\%) with no significant difference to the sham group (9\%). The events reported included worsening of headache and complaints of paraesthesia with treatment. Importantly, no subjects discontinued treatment due to adverse events.

\section{The possible role of transcranial magnetic stimulation $<H 3>($ Table 2)}

Transcranial magnetic stimulation may have a role in the acute treatment of migraine with and without aura. Given its efficacy as an acute treatment, the SpringTMS ${ }^{\circ}$ stimulation device may be of potential benefit in patients who are at risk of overusing acute medications or in 
whom acute medications are ineffective. At present, transcranial magnetic stimulation does not appear effective in the prevention of migraine.

\section{MECHANISMS OF ACTION OF NEUROSTIMULATION<H1>}

\section{Peripheral neurostimulation $<\mathbf{H 2}>$}

The mechanisms by which peripheral neurostimulation modulates an antinociceptive response is still poorly understood. All of the peripheral nerves utilised for neurostimulation project either to the trigeminovascular system (occipital nerve, vagal nerve) or trigeminoautonomic system (sphenopalatine ganglion) which then project to brainstem centres such as the locus coeruleus and periaqueductal gray and further project to higher centres such as the thalamus (Fig 1). This complex network is referred to as "the pain matrix" and functional neuroimaging suggests its major components include the primary and secondary somatosensory cortices, thalamus, anterior and posterior insula, anterior cingulate gyrus and prefrontal cortex.(69) This theory has been examined using functional neuroimaging of patients undergoing occipital nerve stimulation for headache (88-90)and vagal nerve stimulation for depression.(91)

Matharu et al.(88) used positron emission tomography (PET) imaging to study eight patients with chronic migraine who had reported benefit to ONS. Patients were studied in three states: pain-free and stimulation on, in pain with stimulation off and during partial stimulation with varying levels of pain. Significant changes were observed in the regional cerebral blood flow in the dorsal rostral pons, anterior cingulate cortex and cuneus that were related to patient pain scores and changes in the anterior cingulate gyrus and left pulvinar regions correlated to paraesthesia scores. Magis and colleagues studied ten ONS-treated chronic cluster headache patients and compared them to 39 healthy volunteers using PET imaging.(90) ONS patients were scanned at intervals varying between 0 and 30 months post-implant and with stimulation 
on and off. At time of imaging, three cluster patients were pain free and four more had a greater than $90 \%$ reduction in attack frequency. Compared to controls, several areas of the pain matrix showed hyperactivity including the ipsilateral hypothalamus, midbrain and ipsilateral lower pons. Activity in all of these areas normalised with ONS except for the hypothalamus. The anterior cingulate cortex was a possible marker of efficacy as it was seen to be hyperactive in ONS responders compared to non-responders.

Kovacs et al.(89) investigated the potential mechanisms of action in ONS in healthy volunteer studying changes on functional MRI (fMRI) when stimulation was on or off. Significant differences were seen in the activity of the hypothalamus, thalamus, orbitofrontal cortex, prefrontal cortex, periaqueductal gray, inferior parietal regions and cerebellum. Suppression of activity was noted in the somatosensory areas, the amygdala, the hippocampus and primary motor cortex.

The effects on fMRI of a sham-controlled transcutaneous vagal nerve stimulator designed for treatment of depression has been reported.(91) The stimulation device was placed in the left external auditory meatus on the inner side of the tragus, an area known to receive innervation from the vagal nerve. Following stimulation, a reduction in signal was seen in the parahippocampal gyrus, posterior cingulate cortex and right thalamus was observed. Increased signal was observed in the anterior cingulate gyrus. In the brainstem, a significant reduction was seen in signal from the locus coeruleus and solitary tract nucleus.

In summary, simulation of the peripheral nerves is thought to modulate the afferent impulses travelling to the brainstem and higher centres resulting in long-term neuroplastic changes in various regions of the brain, including those outside of the regions stimulated. The finding of persistent hyper-metabolism of the ipsilateral hypothalamus outside of an attack, even after successful ONS, may explain why attacks recur after stimulation is stopped. 


\section{Central neuromodulation $<\mathbf{H 2}>$}

Positron emission tomography studies have implicated the posterior hypothalamic region as being abnormally activated during attacks of cluster headache,(14) SUNCT/SUNA(15) and PH(12). Further anatomical clarification at a later date revealed this area to be the ventral tegmental area and not posterior hypothalamus.(71) This finding has not been replicated in migraine imaging. The imaging findings seem to reinforce the concept of the hypothalamus as an important area in pain regulation and attack generation in TACs. This theory led Leone and colleagues to implant a DBS lead in the area observed on PET imaging in 2000.(70) Ten patients successfully treated with DBS for intractable chronic cluster headache underwent PET imaging to investigate the possible mechanisms behind DBS effect. After ventral tegmental area stimulation activation was observed in the thalamus, somatosensory cortex, cuneus, anterior cingulate cortex and trigeminal nucleus and ganglion and deactivation in the middle temporal gyrus, posterior cingulate cortex and anterior insula. All of these regions are structures involved in the neural circuits of the pain matrix discussed above and thus, similar to ONS, stimulation of the ventral tegmental area appears to result in long-term neuroplastic changes of descending pain processing pathways distant to the site of stimulation itself.

During transcranial magnetic stimulation treatment for migraine a magnetic field is applied to the scalp. This field penetrates the scalp and induces a current in the underlying cortex. The induced electric field alters the membrane potentials, resulting in either depolarisation or repolarisation of a neuronal population. In the treatment of migraine with aura, this current is hypothesised to disrupt CSD as has been observed in animal studies.(92)

\section{CONCLUSIONS <H1}


Primary headache disorders are among the most commonly encountered neurological disorders, yet effective evidence based treatments, particularly the chronic forms, are lacking. With low satisfaction rates for traditional preventative medications due to tolerability and efficacy there is a growing demand for new treatment options for headache patients. Neurostimulation is emerging as a promising treatment option modality particularly for medically intractable chronic migraine and chronic TACs or those with contraindications to other medication. Open-label data is providing evidence that they can improve quality of life in highly disabled chronic headache patients and they can offer hope to many more. However, the quality of current evidence is poor and the ultimate confirmation of any new therapeutic modalities should come from randomised controlled trials. This poses a problem with neurostimulation as the paraesthesia created during treatment with many of these devices creates limits on what would constitute adequate placebo. Another issue with sham stimulation is that the level of current below which clinical effect is lost has not been investigated. It is therefore possible that previous sham studies have been using active placebo rather than control, a situation that complicates interpretation of the data. From available efficacy data, neurostimulation treatments appear to have efficacy similar or below that of available preventative treatments. However, their adverse event and tolerability data (especially in noninvasive devices) is far superior to current medications. At present, the place for neurostimulation seems to lie in two clear patient groups. The first is those with medically intractable chronic headaches where the cost and risk of treatment may be offset by the potential benefit in those with otherwise limited options. The second group is those with contraindications or intolerance to medications. This is a situation where the non-invasive devices may show major potential benefit especially if they can provide effective acute relief. In the future, if robust evidence can be generated, neurostimulation will likely take a prominent 
place in the treatment regimes of headache. However, until such a time, patients must be selected carefully in line with current guidelines. 


\section{REFERENCES: $<$ H1 $>$}

1. Headache Classification Committee of the International Headache Society. The International Classification of Headache Disorders, 3rd edition (beta version). Cephalalgia : an international journal of headache. 2013;33(9):629-808.

2. Stewart WF, Shechter A, Rasmussen BK. Migraine prevalence. A review of population-based studies. Neurology. 1994;44(6 Suppl 4):S17-23.

3. Bjørn Russell M. Epidemiology and genetics of cluster headache. The Lancet Neurology. 2004;3(5):279-83.

4. Sjaastad O, Bakketeig LS. Cluster headache prevalence. Vaga study of headache epidemiology. Cephalalgia : an international journal of headache. 2003;23(7):528-33.

5. World Health Organisation. Atlas of headache disorders and resources in the world 2011. A collaberation project of the World Health Organisation and Lifting the Burden. WHO, 2011.

6. Scher AI, Stewart WF, Liberman J, Lipton RB. Prevalence of frequent headache in a population sample. Headache. 1998;38(7):497-506.

7. Burstein R, Noseda R, Borsook D. Migraine: multiple processes, complex pathophysiology. The Journal of neuroscience : the official journal of the Society for Neuroscience. 2015;35(17):6619-29.

8. Kerr FW, Olafson RA. Trigeminal and cervical volleys. Convergence on single units in the spinal gray at C-1 and C-2. Arch Neurol. 1961;5:171-8.

9. Lipton RB, Pearlman SH. Transcranial magnetic simulation in the treatment of migraine. Neurotherapeutics. 2010;7(2):204-12.

10. Charles AC, Baca SM. Cortical spreading depression and migraine. Nat Rev Neurol. 2013;9(11):637-44.

11. Goadsby PJ, Edvinsson L. Human in vivo evidence for trigeminovascular activation in cluster headache. Neuropeptide changes and effects of acute attacks therapies. Brain : a journal of neurology. 1994;117 ( Pt 3):427-34.

12. Matharu MS, Cohen AS, Frackowiak RS, Goadsby PJ. Posterior hypothalamic activation in paroxysmal hemicrania. Annals of neurology. 2006;59(3):535-45. 
13. Matharu MS, Cohen AS, McGonigle DJ, Ward N, Frackowiak RS, Goadsby PJ. Posterior hypothalamic and brainstem activation in hemicrania continua. Headache. 2004;44(8):747-61.

14. May A, Bahra A, Büchel C, et al. Hypothalamic activation in cluster headache attacks. Lancet. 1998;352:275-8.

15. May A, Bahra A, Buchel C, Turner R, Goadsby PJ. Functional magnetic resonance imaging in spontaneous attacks of SUNCT: short-lasting neuralgiform headache with conjunctival injection and tearing. Annals of neurology. 1999;46(5):791-4.

16. Bartsch T, Levy MJ, Knight YE, Goadsby PJ. Differential modulation of nociceptive dural input to [hypocretin] orexin A and B receptor activation in the posterior hypothalamic area. Pain. 2004;109(3):367-78.

17. Gerardy PY, Fabry D, Fumal A, Schoenen J. A pilot study on supra-orbital surface electrotherapy in migraine. Cephalalagia. 2009;29:101-78.

18. Schoenen J, Vandersmissen B, Jeangette S, Herroelen L, Vandenheede M, Gerard P, et al. Migraine prevention with a supraorbital transcutaneous stimulator: a randomized controlled trial. Neurology. 2013;80(8):697-704.

19. Magis D, Sava S, d'Elia TS, Baschi R, Schoenen J. Safety and patients' satisfaction of transcutaneous supraorbital neurostimulation (tSNS) with the Cefaly $(\mathrm{R})$ device in headache treatment: a survey of 2,313 headache sufferers in the general population. The journal of headache and pain. 2013;14:95.

20. Linde K, Rossnagel K. Propranolol for migraine prophylaxis. The Cochrane database of systematic reviews. 2004(2):CD003225.

21. Asensio-Samper JM, Villanueva VL, Perez AV, Lopez MD, Monsalve V, Moliner S, et al. Peripheral neurostimulation in supraorbital neuralgia refractory to conventional therapy. Pain practice : the official journal of World Institute of Pain. 2008;8(2):120-4.

22. Reed K, Black S, Banta C, Will K. Combined occipital and supraorbital neurostimulation for the treatment of chronic migraine headaches: Initial experience. Cephalalgia : an international journal of headache. 2010;30(3):260-71.

23. Hann S, Sharan A. Dual occipital and supraorbital nerve stimulation for chronic migraine: a single-center experience, review of literature, and surgical considerations. Neurosurgical focus. 2013;35(3):E9.

24. Narouze SN, Kapural L. Supraorbital nerve electric stimulation for the treatment of intractable chronic cluster headache: a case report. Headache. 2007;47(7):1100-2. 
25. Vaisman J, Markley H, Ordia J, Deer T. The treatment of medically intractable trigeminal autonomic cephalalgia with supraorbital/supratrochlear stimulation: a retrospective case series. Neuromodulation : journal of the International Neuromodulation Society. 2012;15(4):374-80.

26. Sadler RM, Purdy RA, Rahey S. Vagal nerve stimulation aborts migraine in patient with intractable epilepsy. Cephalalgia : an international journal of headache. 2002;22(6):4824.

27. Gaul C, Diener HC, Silver N, Magis D, Reuter U, Andersson A, et al. Non-invasive vagus nerve stimulation for PREVention and Acute treatment of chronic cluster headache (PREVA): A randomised controlled study. Cephalalgia : an international journal of headache. 2015 .

28. Nesbitt AD, Marin JC, Tompkins E, Ruttledge MH, Goadsby PJ. Initial use of a novel noninvasive vagus nerve stimulator for cluster headache treatment. Neurology. 2015.

29. Silberstein S, Neves Da Silva A, Calhoun A, Grosberg B, Lipton R, Cady R, et al. NonInvasive Vagus Nerve Stimulation for Chronic Migraine Prevention in a Propective, Randomized, Sham-Controlled Pilot Study (the EVENT Study): Report from the Double-blind Phase. Headache: The Journal of Head and Face Pain. 2014;54:1-74.

30. Silberstein S, Neves Da Silva A, Calhoun A, Grosberg B, R L, Cady R, et al. Chronic Migraine Prevention with non-invasive Vagus Nerve Stimulation in a Prospective Pilot Study (the EVENT Study): Report from the Open-label Phase. Headache: The Journal of Head and Face Pain. 2014;54:1-74.

31. Goadsby P, Grosberg B, Mauskop A, Cady R, Simmons K. Effect of noninvasive vagus nerve stimulation on acute migraine: An open-label pilot study. Cephalalgia : an international journal of headache. 2014;34(12):986-93.

32. Barbanti P, Grazzi L, Egeo G, Padovan AM, Liebler E, Bussone G. Non-invasive vagus nerve stimulation for acute treatment of high-frequency and chronic migraine: an open-label study. The journal of headache and pain. 2015;16:61.

33. Bellavance AJ, Meloche JP. A comparative study of naproxen sodium, pizotyline and placebo in migraine prophylaxis. Headache. 1990;30(11):710-5.

34. Cady RK, Sheftell F, Lipton RB, O'Quinn S, Jones M, Gayla Putnam D, et al. Effect of early intervention with sumatriptan on migraine pain: Retrospective analyses of data from three clinical trials. Clinical Therapeutics. 2000;22(9):1035-48.

35. Krishna V, Sammartino F, King NK, So RQ, Wennberg R. Neuromodulation for Epilepsy. Neurosurgery clinics of North America. 2016;27(1):123-31. 
36. Mauskop A. Vagus nerve stimulation relieves chronic refractory migraine and cluster headaches. Cephalalgia : an international journal of headache. 2005;25(2):82-6.

37. Cecchini AP, Mea E, Tullo V, Curone M, Franzini A, Broggi G, et al. Vagus nerve stimulation in drug-resistant daily chronic migraine with depression: preliminary data. Neurological sciences : official journal of the Italian Neurological Society and of the Italian Society of Clinical Neurophysiology. 2009;30 Suppl 1:S101-4.

38. Hord ED, Evans MS, Mueed S, Adamolekun B, Naritoku DK. The effect of vagus nerve stimulation on migraines. J Pain. 2003;4(9):530-4.

39. Poletti CE. C2 and C3 pain dermatomes in man. Cephalalgia : an international journal of headache. 1991;11(3):155-9.

40. Lipton R, Goadsby PJ, Cady R, Aurora SK, Grosberg BM, Freitag F, et al. PRISM study: Occipital nerve stimulation for treatment-refractory migraine. Cephalalagia. 2009;29(Suppl 1):30.

41. Saper JR, Dodick DW, Silberstein SD, McCarville S, Sun M, Goadsby PJ. Occipital nerve stimulation for the treatment of intractable chronic migraine headache: ONSTIM feasibility study. Cephalalgia : an international journal of headache. 2011;31(3):271-85.

42. Silberstein SD, Dodick DW, Saper J, Huh B, Slavin KV, Sharan A, et al. Safety and efficacy of peripheral nerve stimulation of the occipital nerves for the management of chronic migraine: results from a randomized, multicenter, double-blinded, controlled study. Cephalalgia : an international journal of headache. 2012;32(16):1165-79.

43. Silberstein S, Tfelt-Hansen P, Dodick DW, Limmroth V, Lipton RB, Pascual J, et al. Guidelines for controlled trials of prophylactic treatment of chronic migraine in adults. Cephalalgia : an international journal of headache. 2008;28(5):484-95.

44. Chen YF, Bramley G, Unwin G, Hanu-Cernat D, Dretzke J, Moore D, et al. Occipital nerve stimulation for chronic migraine--a systematic review and meta-analysis. PLoS One. 2015;10(3):e0116786.

45. Mueller O, Diener HC, Dammann P, Rabe K, Hagel V, Sure U, et al. Occipital nerve stimulation for intractable chronic cluster headache or migraine: A critical analysis of direct treatment costs and complications. Cephalalgia : an international journal of headache. 2013;33(16):1283-91.

46. Mueller OM, Gaul C, Katsarava Z, Diener HC, Sure U, Gasser T. Occipital nerve stimulation for the treatment of chronic cluster headache - lessons learned from 18 months experience. Cent Eur Neurosurg. 2011;72(2):84-9. 
47. Magis D, Schoenen J. Advances and challenges in neurostimulation for headaches. The Lancet Neurology. 2012;11(8):708-19.

48. Magis D, Allena M, Bolla M, De Pasqua V, Remacle JM, Schoenen J. Occipital nerve stimulation for drug-resistant chronic cluster headache: a prospective pilot study. The Lancet Neurology. 2007;6(4):314-21.

49. Burns B, Watkins L, Goadsby PJ. Treatment of medically intractable cluster headache by occipital nerve stimulation: long-term follow-up of eight patients. Lancet. 2007;369(9567):1099-106.

50. Burns B, Watkins L, Goadsby PJ. Treatment of intractable chronic cluster headache by occipital nerve stimulation in 14 patients. Neurology. 2009;72(4):341-5.

51. Fontaine D, Christophe Sol J, Raoul S, Fabre N, Geraud G, Magne C, et al. Treatment of refractory chronic cluster headache by chronic occipital nerve stimulation. Cephalalgia : an international journal of headache. 2011;31(10):1101-5.

52. Magis D, Gerardy PY, Remacle JM, Schoenen J. Sustained effectiveness of occipital nerve stimulation in drug-resistant chronic cluster headache. Headache. 2011;51(8):1191-201. 53. Brewer AC, Trentman TL, Ivancic MG, Vargas BB, Rebecca AM, Zimmerman RS, et al. Long-Term Outcome in Occipital Nerve Stimulation Patients With Medically Intractable Primary Headache Disorders. Neuromodulation : journal of the International Neuromodulation Society. 2013;16(6):557-62.

54. Schwedt TJ, Dodick DW, Hentz J, Trentman TL, Zimmerman RS. Occipital nerve stimulation for chronic headache--long-term safety and efficacy. Cephalalgia : an international journal of headache. 2007;27(2):153-7.

55. Lambru G, Shanahan P, Watkins L, Matharu MS. Occipital Nerve Stimulation in the Treatment of Medically Intractable SUNCT and SUNA. Pain physician. 2014;17(1):29-41.

56. Burns B, Watkins L, Goadsby PJ. Treatment of hemicrania continua by occipital nerve stimulation with a bion device: long-term follow-up of a crossover study. The Lancet Neurology. 2008;7(11):1001-12.

57. Schwedt TJ, Dodick DW, Trentman TL, Zimmerman RS. Occipital nerve stimulation for chronic cluster headache and hemicrania continua: pain relief and persistence of autonomic features. Cephalalgia : an international journal of headache. 2006;26(8):1025-7.

58. Weiner RL, Reed KL. Peripheral neurostimulation for control of intractable occipital neuralgia. Neuromodulation : journal of the International Neuromodulation Society. $1999 ; 2(3): 217-21$. 
59. Popeney CA, Alo KM. Peripheral neurostimulation for the treatment of chronic, disabling transformed migraine. Headache. 2003;43(4):369-75.

60. Johnstone CS, Sundaraj R. Occipital nerve stimulation for the treatment of occipital neuralgia-eight case studies. Neuromodulation : journal of the International Neuromodulation Society. 2006;9(1):41-7.

61. Slavin KV, Nersesyan H, Wess C. Peripheral neurostimulation for treatment of intractable occipital neuralgia. Neurosurgery. 2006;58(1):112-9; discussion -9.

62. Paemeleire K, Van Buyten JP, Van Buynder M, Alicino D, Van Maele G, Smet I, et al. Phenotype of patients responsive to occipital nerve stimulation for refractory head pain. Cephalalgia : an international journal of headache. 2010;30(6):662-73.

63. Palmisani S, Al-Kaisy A, Arcioni R, Smith T, Negro A, Lambru G, et al. A six year retrospective review of occipital nerve stimulation practice--controversies and challenges of an emerging technique for treating refractory headache syndromes. The journal of headache and pain. 2013;14:67.

64. Dodick DW, Silberstein SD, Reed KL, Deer TR, Slavin KV, Huh B, et al. Safety and efficacy of peripheral nerve stimulation of the occipital nerves for the management of chronic migraine: Long-term results from a randomized, multicenter, double-blinded, controlled study. Cephalalgia : an international journal of headache. 2015;35(4):344-58.

65. Sharan A, Huh B, Narouze S, Trentman T, Mogilner A, Vaisman J, et al. Analysis of Adverse Events in the Management of Chronic Migraine by Peripheral Nerve Stimulation. Neuromodulation : journal of the International Neuromodulation Society. 2015;18

(4):305-12.

66. Schoenen J, Jensen RH, Lanteri-Minet M, Lainez MJ, Gaul C, Goodman AM, et al. Stimulation of the sphenopalatine ganglion (SPG) for cluster headache treatment. Pathway CH1: A randomized, sham-controlled study. Cephalalgia : an international journal of headache. 2013;33(10):816-30.

67. Jurgens TP, Schoenen J, Rostgaard J, Hillerup S, Lainez MJ, Assaf AT, et al. Stimulation of the sphenopalatine ganglion in intractable cluster headache: Expert consensus on patient selection and standards of care. Cephalalgia : an international journal of headache. 2014.

68. Bahra A, Matharu MS, Buchel C, Frackowiak RS, Goadsby PJ. Brainstem activation specific to migraine headache. Lancet. 2001;357(9261):1016-7. 
69. May A. A review of diagnostic and functional imaging in headache. The journal of headache and pain. 2006;7(4):174-84.

70. Leone M, Franzini A, Bussone G. Stereotactic stimulation of posterior hypothalamic gray matter in a patient with intractable cluster headache. The New England journal of medicine. 2001;345(1428-1429).

71. Matharu MS, Zrinzo L. Deep brain stimulation in cluster headache: hypothalamus or midbrain tegmentum? Current pain and headache reports. 2010;14(2):151-9.

72. Fontaine D, Lazorthes Y, Mertens P, Blond S, Geraud G, Fabre N, et al. Safety and efficacy of deep brain stimulation in refractory cluster headache: a randomized placebocontrolled double-blind trial followed by a 1-year open extension. The journal of headache and pain. 2010;11(1):23-31.

73. Leone M, Franzini A, Broggi G, Mea E, Cecchini AP, Bussone G. Acute hypothalamic stimulation and ongoing cluster headache. Neurology. 2006;67:1844-5.

74. Bartsch T, Pinsker MO, Rasche D, et al. Hypothalamic deep brain stimulation for cluster headache: experience from a new multicase series. Cephalalgia : an international journal of headache. 2008;28:285-95.

75. Starr PA, Barbaro NM, Raskin NH, Ostrem JL. Chronic stimulation of the posterior hypothalamus region for cluster headache: technique and 1-year results in four patients. $\mathrm{J}$ Neurosurg. 2007;106(999-1005).

76. Schoenen J, Di Clemente L, Vandenheede M, Fumal A, De Pasqua V, Mouchamps M, et al. Hypothalamic stimulation in chronic cluster headache: a pilot study of efficacy and mode of action. Brain : a journal of neurology. 2005;128(Pt 4):940-7.

77. Franzini A, Messina G, Cordella R, Marras C, Broggi G. Deep brain stimulation of the posteromedial hypothalamus: indications, long-term results and neurophysiological considerations. Neurosurgical focus. 2010;29(2):1-13.

78. Seijo F, Saiz A, Lozano B, Santamarta E, Alvarez-Vega M, Seijo E, et al. Neuromodulation of the posterolateral hypothalamus for the treatment of chronic refractory cluster headache: Experience in five patients with a modified anatomical target. Cephalalgia : an international journal of headache. 2011;31(16):1634-41.

79. Leone M, Franzini A, Proietti Cecchini A, Bussone G. Success, failure, and putative mechanisms in hypothalamic stimulation for drug-resistant chronic cluster headache. Pain. 2013;154(1):89-94. 
80. Martelletti P, Jensen RH, Antal A, Arcioni R, Brighina F, de Tommaso M, et al. Neuromodulation of chronic headaches: position statement from the European Headache Federation. The journal of headache and pain. 2013;14(1):86.

81. Leone M, Franzini A, D'Andrea G, Broggi G, Casucci G, Bussone G. Deep brain stimulation to relieve drug-resistant SUNCT. Annals of neurology. 2005;57(6):924-7.

82. Bartsch T, Falk D, Knudsen K, Reese R, Raethjen J, Mehdorn HM, et al. Deep brain stimulation of the posterior hypothalamic area in intractable short-lasting unilateral neuralgiform headache with conjunctival injection and tearing (SUNCT). Cephalalgia : an international journal of headache. 2011;31(13):1405-8.

83. Lyons MK, Dodick DW, Evidente VG. Responsiveness of short-lasting unilateral neuralgiform headache with conjunctival injection and tearing to hypothalamic deep brain stimulation. J Neurosurg. 2009;110(2):279-81.

84. Miller S, Rasul F, Lambru G, Lagrata S, Hariz GM, Zrinzo L, et al. Posterior Hypothalamic Region Deep Brain Stimulation in Shoer Lasting Unilateral Neuralgiform Headache with Conjunctival Injection and Tearing (SUNCT). Cephalalgia : an international journal of headache. 2013;33(8 Suppl):1-309.

85. Lipton RB, Dodick DW, Silberstein SD, Saper JR, Aurora SK, Pearlman SH, et al. Single-pulse transcranial magnetic stimulation for acute treatment of migraine with aura: a randomised, double-blind, parallel-group, sham-controlled trial. The Lancet Neurology. 2010;9(4):373-80.

86. Bhola R, Kinsella E, Giffin N, Lipscombe S, Ahmed F, Weatherall M, et al. Singlepulse transcranial magnetic stimulation (sTMS) for the acute treatment of migraine: evaluation of outcome data for the UK post market pilot program. The journal of headache and pain. $2015 ; 16: 535$.

87. Dodick DW, Schembri CT, Helmuth M, Aurora SK. Transcranial magnetic stimulation for migraine: a safety review. Headache. 2010;50(7):1153-63.

88. Matharu MS, Bartsch T, Ward N, Frackowiak RS, Weiner R, Goadsby PJ. Central neuromodulation in chronic migraine patients with suboccipital stimulators: a PET study. Brain : a journal of neurology. 2004;127(Pt 1):220-30.

89. Kovacs S, Peeters R, De Ridder D, Plazier M, Menovsky T, Sunaert S. Central Effects of Occipital Nerve Electrical Stimulation Studied by Functional Magnetic Resonance Imaging. Neuromodulation: Technology at the Neural Interface. 2011;14(1):46-57. 
90. Magis D, Bruno MA, Fumal A, Gerardy PY, Hustinx R, Laureys S, et al. Central modulation in cluster headache patients treated with occipital nerve stimulation: an FDG-PET study. BMC Neurol. 2011;11:25.

91. Kraus T, Kiess O, Hosl K, Terekhin P, Kornhuber J, Forster C. CNS BOLD fMRI effects of sham-controlled transcutaneous electrical nerve stimulation in the left outer auditory canal - a pilot study. Brain Stimul. 2013;6(5):798-804.

92. Holland PR, Schembri CT, Fredrick J, Goadsby P. Transcranial magnetic stimulation for the treamtent of migraine aura? Cephalalgia : an international journal of headache. 2009;29(1 suppl):22.

93. Magis D. Neuromodulation in migraine: state of the art and perspectives. Expert Rev Med Devices. 2015;12(3):329-39.

94. Leone M, Proietti Cecchini A, Mea E, D'Amico D, Tullo V, Grazzi L, et al. Therapeutic neurostimulation in chronic headaches: problems of patient selection. Neurological sciences : official journal of the Italian Neurological Society and of the Italian Society of Clinical Neurophysiology. 2008;29 Suppl 1:S59-61. 
Page | 40 


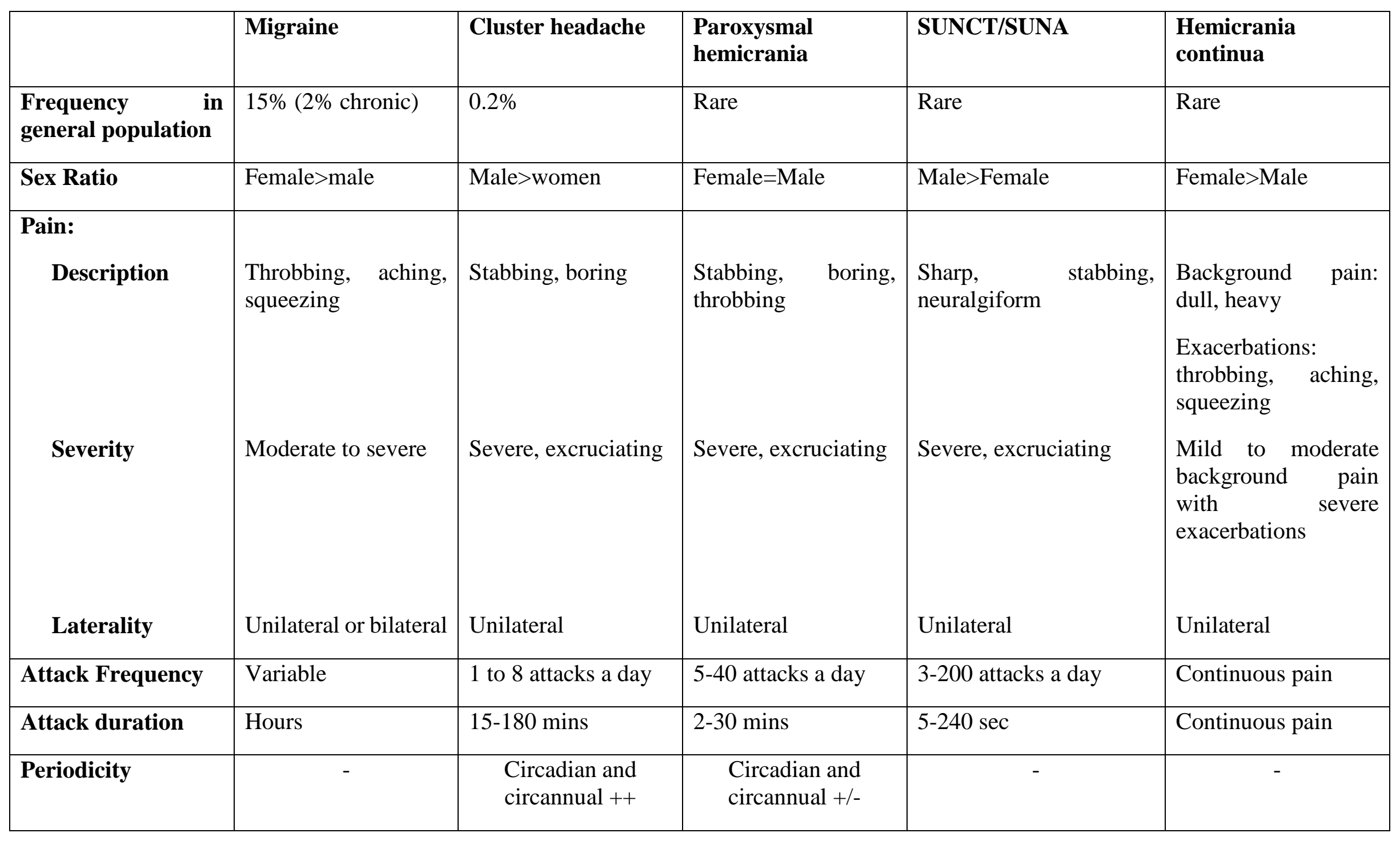




\begin{tabular}{|c|c|c|c|c|c|}
\hline $\begin{array}{l}\text { Autonomic } \\
\text { features* }\end{array}$ & Sometimes, mild & Yes & Yes & Yes & $\begin{array}{c}\text { Yes, with } \\
\text { exacerbations }\end{array}$ \\
\hline $\begin{array}{l}\text { Migrainous } \\
\text { features } * *\end{array}$ & Yes & Yes, may be mild & Yes, may be mild & Rare & Yes \\
\hline \multicolumn{6}{|l|}{ Triggers } \\
\hline Alcohol & Yes & Yes & No & No & No \\
\hline Cutaneous touch & No & No & No & Yes & No \\
\hline $\begin{array}{l}\text { Indometacin } \\
\text { response }\end{array}$ & None & None & Complete resolution & None & Complete resolution \\
\hline Abortive treatment & Oral triptan, NSAID & $\begin{array}{c}\text { Subcutaneous } \\
\text { Sumatriptan, } \\
\text { Oxygen }\end{array}$ & Nil & Nil & Nil \\
\hline $\begin{array}{l}\text { First-line } \\
\text { prophylactic }\end{array}$ & $\begin{array}{l}\text { Beta-Blockers, } \\
\text { tricyclic } \\
\text { antidepressant, } \\
\text { topiramate }\end{array}$ & $\begin{array}{l}\text { Verapamil, lithium, } \\
\text { topiramate }\end{array}$ & Indometacin & $\begin{array}{l}\text { Lamotrigine, } \\
\text { oxcarbazepine }\end{array}$ & Indometacin \\
\hline
\end{tabular}

NSAID, non-steroidal anti-inflammatory drugs; SUNA, short-lasting unilateral neuralgiform headache attacks with autonomic features;

SUNCT, short-lasting unilateral neuralgiform headache attacks with conjunctival injection and tearing;

* Autonomic features: One or more of ptosis, lacrimation, conjunctival injection, facial redness/sweating, eyelid/facial swelling, nasal stuffiness, rhinorrhea

** Migrainous features: One or more of nausea and/or vomiting, photophobia, phonophobia

Table 1. Clinical features of the primary headache disorders 


\begin{tabular}{|c|c|c|c|c|c|c|}
\hline & $\begin{array}{c}\text { Supraorbital } \\
\text { Stimulation }\end{array}$ & $\begin{array}{l}\text { Vagal Nerve } \\
\text { Stimulation }\end{array}$ & $\begin{array}{l}\text { Transcranial } \\
\text { Magnetic } \\
\text { Stimulation }\end{array}$ & $\begin{array}{l}\text { Occipital Nerve } \\
\text { Stimulation }\end{array}$ & $\begin{array}{c}\text { Sphenopalatine } \\
\text { Ganglion } \\
\text { Stimulation }\end{array}$ & $\begin{array}{l}\text { Deep Brain } \\
\text { Stimulation }\end{array}$ \\
\hline \multicolumn{7}{|l|}{ Treatment Use } \\
\hline $\begin{array}{l}\text { Prevention of } \\
\text { episodic migraine }\end{array}$ & $\sqrt{ }$ & $\mathrm{X}$ & $\mathrm{X}$ & $\mathrm{X}$ & $\mathrm{X}$ & $\mathrm{X}$ \\
\hline $\begin{array}{l}\text { Prevention of } \\
\text { chronic migraine }\end{array}$ & $\mathrm{X}$ & $\mathrm{X}$ & $\mathrm{X}$ & $\sqrt{ }$ & $\mathrm{X}$ & $\mathrm{X}$ \\
\hline $\begin{array}{l}\text { Prevention of } \\
\text { chronic cluster } \\
\text { headache }\end{array}$ & $\mathrm{X}$ & $\sqrt{ }$ & $\mathrm{X}$ & $\sqrt{ }$ & $\sqrt{ }$ (studies on-going) & $\sqrt{ }$ \\
\hline Other TACs & $\mathrm{X}$ & $\mathrm{X}$ & $\mathrm{X}$ & $\begin{array}{c}\sqrt{ } \\
\text { (prevention of chronic } \\
\text { intractable TACs) }\end{array}$ & $\bar{X}$ & $\begin{array}{c}\sqrt{ } \\
\text { (prevention of chronic } \\
\text { intractable TACs) }\end{array}$ \\
\hline
\end{tabular}

TACs, Trigeminal Autonomic Cephalalgias 
*Usefulness may be dictated by length of episodic cluster bout, if bout lasts less than 3 months may be difficult to assess as treatment may take this long to have clear effect

Table 2: Summary table of the possible roles of neurostimulation in primary headache disorders 


\begin{tabular}{|c|c|c|c|}
\hline Trial (first author, year) & Patients (n) & Average follow-up (months) & $\begin{array}{l}\text { Response rate } \\
\text { (proportion reporting at least } \\
50 \% \text { reduction in attack } \\
\text { frequency) }\end{array}$ \\
\hline \multicolumn{4}{|c|}{ Supraorbital nerve stimulation (+/- ONS) for chronic migraine } \\
\hline Reed et al.(22) & 7 & 17 & $100 \%$ \\
\hline Hann and Sharan(23) & 14 & 31 & $71 \% *$ \\
\hline TOTAL & 21 & 16 & $86 \%$ \\
\hline \multicolumn{4}{|l|}{ ONS for chronic migraine } \\
\hline Saper et al.(41) & 75 & 3 months & $39 \% * *$ \\
\hline $\begin{array}{l}\text { Silberstein } \text { et al.(42) } \\
\text { [Extended follow up, Dodick et } \\
\text { al.(64) ] }\end{array}$ & $\begin{array}{l}157 \\
{[157]}\end{array}$ & $\begin{array}{l}3 \text { months } \\
\text { [12 months] }\end{array}$ & $\begin{array}{l}17 \% \\
{[60 \%]}\end{array}$ \\
\hline Brewer et al.(53) & 12 & 34 months & $42 \%$ \\
\hline Lipton et al.(40) & 125 & 3 months & $\begin{array}{l}\text { N/A (-6 days week active group vs. }-4 \\
\text { days week sham group, } p=0.29 \text { ) }\end{array}$ \\
\hline Mueller et al.(45) & 3 & 7 month & $100 \% * * *$ \\
\hline Paemeleire et al.(62) & 8 & 24 month & $71 \% * * * *$ \\
\hline TOTAL & 380 & 12 month & $42 \%$ \\
\hline
\end{tabular}




\begin{tabular}{|c|c|c|c|}
\hline & & & [53\%] \\
\hline \multicolumn{4}{|c|}{ ONS for chronic cluster headache } \\
\hline Magis et al. $(48,52)$ & 14 & 37 & $86 \%$ \\
\hline Schwedt et al.(54) & 3 & 19 & $33 \%$ \\
\hline Brewer et al.(53) & 5 & 41 & $80 \%$ \\
\hline Burns et al. $(49,50)$ & 14 & 18 & $36 \%$ \\
\hline Fontaine et al.(51) & 13 & 15 & $77 \%$ \\
\hline Mueller et al. (45) & 24 & 22 month & $88 \% * * *$ \\
\hline Mueller et al.(46) & 10 & 12 month & $90 \% * * *$ \\
\hline TOTAL & 83 & 23 month & $62 \%$ \\
\hline \multicolumn{4}{|c|}{ ONS for SUNCT/SUNA } \\
\hline Lambru et al.(55) & 9 & 38 month & $89 \%$ \\
\hline \multicolumn{4}{|c|}{ ONS for hemicrania continua } \\
\hline Burns et al.(56) & 6 & 14 & $67 \%$ \\
\hline
\end{tabular}


ONS, occipital nerve stimulation; SUNCT, short-lasting unilateral neuralgiform headache attacks with conjunctival injection and tearing; SUNA, short-lasting unilateral neuralgiform headache attacks with autonomic features

*Clinical response defined as least $50 \%$ reduction in headache severity

**Clinical response defined as least $50 \%$ reduction in monthly headache days or greater than 3 point reduction verbal rating scale

*** Definition of response not given/unclear, not included in response rate total

**** response defined by least 3 point reduction verbal rating scale

[ ] data from extended follow-up of the original Silberstein (2012) series

Table 3: Evidence from published case series for occipital nerve stimulation in primary headache conditions 


\begin{tabular}{|c|c|c|c|c|c|c|c|c|c|c|c|}
\hline Author & $\begin{array}{l}\text { Number } \\
\text { patients }\end{array}$ & $\begin{array}{l}\text { Duration } \\
\text { follow-up } \\
\text { (mean) }\end{array}$ & $\begin{array}{l}\text { Hardware } \\
\text { complications }\end{array}$ & related & $\begin{array}{l}\text { Surgical } \\
\text { action } \\
\text { required }\end{array}$ & $\begin{array}{l}\text { Biological } \\
\text { complications }\end{array}$ & related & $\begin{array}{l}\text { Surgical } \\
\text { action } \\
\text { required }\end{array}$ & $\begin{array}{l}\text { Stimulation } \\
\text { complication }\end{array}$ & $\begin{array}{r}\text { related } \\
\text { s }\end{array}$ & $\begin{array}{l}\text { Surgical } \\
\text { action } \\
\text { required }\end{array}$ \\
\hline $\begin{array}{l}\text { Weiner and } \\
\text { Reed (58) }\end{array}$ & 13 & 2.4 years & Migration & $1(8 \%)$ & $1(8 \%)$ & Infection & $1(8 \%)$ & $1(8 \%)$ & & & \\
\hline $\begin{array}{l}\text { Popeney } \\
\text { and Alo } \\
(59)\end{array}$ & 25 & $\begin{array}{c}18.3 \\
\text { months }\end{array}$ & $\begin{array}{l}\text { Migration } \\
\text { Re-implantation } \\
\text { post infection }\end{array}$ & $\begin{array}{c}9(36 \%) \\
1(4 \%)\end{array}$ & $\begin{array}{c}0(36 \%) \\
1(4 \%)\end{array}$ & Infection & $1(4 \%)$ & $1(4 \%)$ & & & \\
\hline $\begin{array}{l}\text { Fontaine et } \\
\text { al. (51) }\end{array}$ & 20 & $\begin{array}{l}6 \text { months- } \\
4 \text { years } \\
\text { (no mean } \\
\text { given) }\end{array}$ & $\begin{array}{l}\text { Migration } \\
\text { Explantation } \\
\text { (headache free) } \\
\text { Battery failure }\end{array}$ & $\begin{array}{l}7(35 \%) \\
1(5 \%) \\
1(5 \%)\end{array}$ & $\begin{array}{l}7(35 \%) \\
1(5 \%) \\
1(5 \%)\end{array}$ & Infection & $2(10 \%)$ & $1(5 \%)$ & & & \\
\hline $\begin{array}{l}\text { Johnstone } \\
\text { and } \\
\text { Sundaraj } \\
(60)\end{array}$ & 7 & 25 months & $\begin{array}{l}\text { Re-implantation } \\
\text { post infection }\end{array}$ & $2(29 \%)$ & $2(29 \%)$ & Infection & $2(29 \%)$ & $2(29 \%)$ & & & \\
\hline $\begin{array}{l}\text { Slavin et al. } \\
\text { (61) }\end{array}$ & 10 & 22 months & $\begin{array}{l}\text { Migration } \\
\text { Explantation } \\
\text { (headache free) }\end{array}$ & $\begin{array}{l}1(10 \%) \\
1(10 \%)\end{array}$ & $\begin{array}{l}1(10 \%) \\
1(10 \%)\end{array}$ & $\begin{array}{l}\text { Infection } \\
\text { Neck pain }\end{array}$ & $\begin{array}{l}1(10 \%) \\
1(10 \%)\end{array}$ & $\begin{array}{l}1(10 \%) \\
1(10 \%)\end{array}$ & & & \\
\hline $\begin{array}{l}\text { Magis et al. } \\
(93)\end{array}$ & 8 & $\begin{array}{c}15.1 \\
\text { months }\end{array}$ & $\begin{array}{l}\text { Migration } \\
\text { Lead fracture/ } \\
\text { displacement } \\
\text { Battery failure }\end{array}$ & $\begin{array}{l}1(13 \%) \\
1(13 \%) \\
4(50 \%)\end{array}$ & $\begin{array}{c}0 \\
0 \\
4(50 \%)\end{array}$ & $\begin{array}{l}\text { IPG/Lead/Wou } \\
\text { nd pain }\end{array}$ & $2(25 \%)$ & 0 & $\begin{array}{l}\text { Undesirable } \\
\text { changes in } \\
\text { stimulation }\end{array}$ & $1(13 \%)$ & $1(13 \%)$ \\
\hline $\begin{array}{l}\text { Schwedt et } \\
\text { al. (54) }\end{array}$ & 15 & 3 year & $\begin{array}{l}\text { Migration } \\
\text { Battery failure }\end{array}$ & $\begin{array}{l}8(53 \%) \\
5(33 \%)\end{array}$ & $\begin{array}{l}\text { N/A } \\
\text { N/A }\end{array}$ & $\begin{array}{l}\text { IPG, Lead or } \\
\text { Wound pain } \\
\text { Neck stiffness }\end{array}$ & $\begin{array}{l}12(80 \%) \\
5(33 \%)\end{array}$ & $\begin{array}{l}\text { N/A } \\
\text { N/A }\end{array}$ & & & \\
\hline
\end{tabular}




\begin{tabular}{|c|c|c|c|c|c|c|c|c|c|c|c|}
\hline & & & & & & $\begin{array}{l}\text { Wound site } \\
\text { complications }\end{array}$ & $4(27 \%)$ & N/A & & & \\
\hline $\begin{array}{l}\text { Burns et al. } \\
\text { (50) }\end{array}$ & 14 & $\begin{array}{c}17.5 \\
\text { months }\end{array}$ & $\begin{array}{l}\text { Migration } \\
\text { Lead fracture/ } \\
\text { displacement } \\
\text { Explantation } \\
\text { (lack efficacy) } \\
\text { Battery failure } \\
\text { Additional } \\
\text { electrode }\end{array}$ & $\begin{array}{l}3(21 \%) \\
2(14 \%) \\
1(7 \%) \\
8(57 \%) \\
1(7 \%)\end{array}$ & $\begin{array}{c}3(21 \%) \\
2(14 \%) \\
1(7 \%) \\
6(57 \%) \\
1(7 \%)\end{array}$ & $\begin{array}{l}\text { Infection } \\
\text { IPG, Lead or } \\
\text { Wound pain } \\
\text { Neck stiffness } \\
\text { Wound site } \\
\text { complications }\end{array}$ & $\begin{array}{l}3(21 \%) \\
4(29 \%) \\
1(7 \%) \\
1(7 \%)\end{array}$ & $\begin{array}{l}0 \\
0 \\
0 \\
0\end{array}$ & $\begin{array}{l}\text { Undesirable } \\
\text { changes in } \\
\text { stimulation }\end{array}$ & $4(29 \%)$ & 0 \\
\hline $\begin{array}{l}\text { Lipton et } \\
\text { al. }(40) \\
\text { [Data from } \\
\text { (Sharan et } \\
\text { al.(65)] }\end{array}$ & 125 & 12 week & Migration & $7 \%$ & N/A & $\begin{array}{l}\text { Infection } \\
\text { IPG, Lead or } \\
\text { Wound pain }\end{array}$ & $\begin{array}{c}15 \% \\
8 \%\end{array}$ & $\begin{array}{l}\text { N/A } \\
\text { N/A }\end{array}$ & & & \\
\hline $\begin{array}{l}\text { Paemeleire } \\
\text { et al. (62) }\end{array}$ & 44 & 36 months & $\begin{array}{l}\text { Migration } \\
\text { Lead fracture/ } \\
\text { displacement }\end{array}$ & $\begin{array}{c}2(5 \%) \\
9(21 \%)\end{array}$ & $\begin{array}{c}2(5 \%) \\
9(21 \%)\end{array}$ & $\begin{array}{l}\text { Infection } \\
\text { IPG, Lead or } \\
\text { Wound pain }\end{array}$ & $\begin{array}{l}2(5 \%) \\
3(7 \%)\end{array}$ & $\begin{array}{c}0 \\
3(7 \%)\end{array}$ & & & \\
\hline $\begin{array}{l}\text { Saper et al. } \\
\text { (41) }\end{array}$ & 51 & 3 month & $\begin{array}{l}\text { Migration } \\
\text { Lead fracture }\end{array}$ & $\begin{array}{c}12(24 \%) \\
1(2 \%)\end{array}$ & $\begin{array}{l}\text { N/A } \\
\text { N/A }\end{array}$ & $\begin{array}{l}\text { Infection } \\
\text { IPG, Lead or } \\
\text { Wound pain } \\
\text { Neck stiffness } \\
\text { Wound site } \\
\text { complication }\end{array}$ & $\begin{array}{c}12(24 \%) \\
5(10 \%) \\
2(4 \%) \\
4(8 \%)\end{array}$ & $\begin{array}{l}\text { N/A } \\
\text { N/A } \\
\text { N/A } \\
\text { N/A }\end{array}$ & $\begin{array}{l}\text { Undesirable } \\
\text { changes in } \\
\text { stimulation } \\
3 \\
(6 \%)\end{array}$ & & N/A \\
\hline
\end{tabular}




\begin{tabular}{|c|c|c|c|c|c|c|c|c|c|c|c|}
\hline $\begin{array}{l}\text { Fontaine et } \\
\text { al. (51) }\end{array}$ & 13 & $\begin{array}{c}14.6 \\
\text { months }\end{array}$ & & & & $\begin{array}{l}\text { Infection } \\
\text { Wound site } \\
\text { complication }\end{array}$ & $\begin{array}{l}1(8 \%) \\
1(8 \%)\end{array}$ & $\begin{array}{l}1(8 \%) \\
1(8 \%)\end{array}$ & $\begin{array}{l}\text { Undesirable } \\
\text { changes in } \\
\text { stimulation }\end{array}$ & $1(8 \%)$ & 0 \\
\hline $\begin{array}{l}\text { Magis et al. } \\
(52)\end{array}$ & 15 & $\begin{array}{c}36.8 \\
\text { months }\end{array}$ & $\begin{array}{l}\text { Migration } \\
\text { Battery failure }\end{array}$ & $\begin{array}{c}1(7 \%) \\
9(60 \%)\end{array}$ & $\begin{array}{c}1(7 \%) \\
9(60 \%)\end{array}$ & $\begin{array}{l}\text { Infection } \\
\text { IPG, Lead or } \\
\text { Wound pain }\end{array}$ & $\begin{array}{l}3(20 \%) \\
5(33 \%)\end{array}$ & $\begin{array}{c}3(20 \%) \\
0\end{array}$ & $\begin{array}{l}\text { Undesirable } \\
\text { changes in } \\
\text { stimulation }\end{array}$ & $3(20 \%)$ & $1(7 \%)$ \\
\hline $\begin{array}{l}\text { Brewer et } \\
\text { al. (53) }\end{array}$ & 26 & 8.5 years & $\begin{array}{l}\text { Migration } \\
\text { Explantation } \\
\text { (headache free } \\
\text { x2, lack efficacy } \\
\text { x3) } \\
\text { Battery failure } \\
\text { Lead revisions }\end{array}$ & $\begin{array}{c}1(4 \%) \\
5(19 \%) \\
\\
1(4 \%) \\
15(58 \%)\end{array}$ & $\begin{array}{c}0 \\
5(19 \%) \\
\\
0 \\
15(58 \%)\end{array}$ & Infection & $1(4 \%)$ & $1(4 \%)$ & & & \\
\hline $\begin{array}{l}\text { Silberstein } \\
\text { et al. (42) }\end{array}$ & 157 & 12 weeks & $\begin{array}{l}\text { Migration } \\
\text { Lead fracture/ } \\
\text { displacement } \\
\text { Erosion }\end{array}$ & $\begin{array}{c}20(13 \%) \\
2(1 \%) \\
7(5 \%)\end{array}$ & $\begin{array}{l}\text { N/A } \\
\text { N/A } \\
\text { N/A }\end{array}$ & $\begin{array}{l}\text { Infection } \\
\text { IPG, Lead or } \\
\text { Wound pain } \\
\text { Wound site } \\
\text { complication } \\
\text { Allergy to } \\
\text { surgical } \\
\text { material }\end{array}$ & $\begin{array}{c}7(5 \%) \\
23(15 \%) \\
4(3 \%) \\
4(3 \%)\end{array}$ & $\begin{array}{l}\text { N/A } \\
\text { N/A } \\
\text { N/A } \\
\text { N/A }\end{array}$ & $\begin{array}{l}\text { Undesirable } \\
\text { changes in } \\
\text { stimulation }\end{array}$ & $9(6 \%)$ & N/A \\
\hline $\begin{array}{l}\text { Palmisani } \\
\text { et al. }(63)\end{array}$ & 23 & 36 months & $\begin{array}{l}\text { Migration } \\
\text { Fracture } \\
\text { Erosion } \\
\text { (all with } \\
\text { associated } \\
\text { infection) }\end{array}$ & & $\begin{array}{c}3(13 \%) \\
2(9 \%) \\
3(13 \%)\end{array}$ & Infection & & $2(9 \%)$ & $\begin{array}{l}\text { Undesirable } \\
\text { changes in } \\
\text { stimulation }\end{array}$ & & $2(9 \%)$ \\
\hline
\end{tabular}




\begin{tabular}{|c|c|c|c|c|c|c|c|c|c|c|c|}
\hline & & & $\begin{array}{l}\text { Explantation } \\
\text { (lack efficacy) }\end{array}$ & & $4(17 \%)$ & & & & & & \\
\hline $\begin{array}{l}\text { Dodick et } \\
\text { al.(64) }\end{array}$ & 157 & 52 weeks & $\begin{array}{l}\text { Migration } \\
\text { Lead fracture/ } \\
\text { displacement } \\
\text { Skin erosion } \\
\text { Battery failure }\end{array}$ & $\begin{array}{l}29(19 \%) \\
7(4 \%) \\
8(5 \%) \\
8(5 \%)\end{array}$ & $\begin{array}{c}27(17 \%) \\
7(4 \%) \\
7(4 \%) \\
7(4 \%)\end{array}$ & $\begin{array}{l}\text { Infection } \\
\text { IPG, Lead or } \\
\text { Wound pain } \\
\text { Wound site } \\
\text { complication } \\
\begin{array}{l}\text { Allergy to } \\
\text { surgical } \\
\text { material }\end{array}\end{array}$ & $\begin{array}{c}11(7 \%) \\
38(24 \%) \\
6(3 \%) \\
5(3 \%)\end{array}$ & $\begin{array}{c}6(4 \%) \\
12(8 \%) \\
1(1 \%) \\
2(1 \%)\end{array}$ & $\begin{array}{l}\text { Undesirable } \\
\text { changes in } \\
\text { stimulation }\end{array}$ & $17(11 \%)$ & $8(5 \%)$ \\
\hline
\end{tabular}

IPG, Implantable pulse generator; N/A, Data not available from paper

Table 4: Adverse reactions reported in published occipital nerve stimulation series. 
- Patient must meet the International Headache Society criteria for chronic migraine or trigeminal autonomic cephalalgia

- For chronic cluster headache, patients should have had daily or near daily attacks for at least two years prior to stimulation

- Patients should have been under the care of a headache specialist team for at least one year

- All reasonable drugs must have been tried at the correct doses and for sufficient durations unless contraindicated

- All patients should have a psychological assessment prior to surgery

- All co-existent conditions should be identified and treated where possible prior to surgery (e.g. depression, medication overuse)

- Patients (and doctors) must have a realistic expectation of the surgical outcome

- Patients should be followed up by the headache specialist team for at least one year

- Prospective headache diaries recording headache attack frequency, severity and duration as well as analgesia intake must be kept

- Appropriate quality of life measures, disability scores and self-assessments must be kept by the patient prior and post-operatively

- Where possible the neurostimulator should only be switched off for efficacy assessment, ideally in a double-blind fashion.

- A clear record of adverse events is kept

Table 5. Criteria for the use of invasive neurostimulation in primary headache

[adapted from Martelletti et al.(80) and Leone et al.(94)] 


\begin{tabular}{|c|c|c|c|c|}
\hline $\begin{array}{l}\text { Trial (first } \\
\text { author, year) }\end{array}$ & $\begin{array}{l}\text { Patients } \\
\text { (n) }\end{array}$ & $\begin{array}{l}\text { Average } \\
\text { follow-up } \\
\text { (months) }\end{array}$ & $\begin{array}{l}\text { Response rate } \\
\text { (Proportion } \\
\text { reporting least } \\
50 \% \text { reduction } \\
\text { attack frequency) }\end{array}$ & Adverse Events (n) \\
\hline \multicolumn{5}{|c|}{ DBS for chronic cluster headache } \\
\hline $\begin{array}{l}\text { Schoenen et al. } \\
\text { (76) }\end{array}$ & $\begin{array}{l}4 \quad(6 \\
\text { implante } \\
\text { d) }\end{array}$ & 15 months & $75 \%$ & $\begin{array}{l}\text { Fatal intracerebral } \\
\text { haemorrhage (1), } \\
\text { severe anxiety attack } \\
\text { at time of implant (1) }\end{array}$ \\
\hline $\begin{array}{l}\text { Franzini et al. } \\
\text { (77) }\end{array}$ & 5 & 12 month & $100 \%$ pain free & \\
\hline Seijo et al.(78) & 5 & 33 months & $100 \%$ & $\begin{array}{l}\text { Meiosis (3), Cable } \\
\text { rupture (2) }\end{array}$ \\
\hline $\begin{array}{l}\text { Bartsch et al. } \\
\text { (74) }\end{array}$ & 6 & 17 month & $50 \%$ & Cable revision (1) \\
\hline $\begin{array}{l}\text { Fontaine et al. } \\
\text { (72) }\end{array}$ & 11 & 12 month & $55 \%$ & Infection (1) \\
\hline $\begin{array}{l}\text { Leone et al. } \\
\text { (79) }\end{array}$ & 17 & 108 month & $70 \%$ & $\begin{array}{l}\text { Electrode migration } \\
(2), \text { infection (4), } \\
\text { intraventricular } \\
\text { haemorrhage } \\
\text { seizure (1) }\end{array}$ \\
\hline Starr et al. (75) & 4 & 12 month & $50 \%$ & $\begin{array}{l}\text { Transient ischaemic } \\
\text { attack (1) }\end{array}$ \\
\hline TOTAL & 52 & 30 month & $71 \%$ & \\
\hline \multicolumn{5}{|c|}{ DBS for SUNCT/SUNA } \\
\hline $\begin{array}{l}\text { Lyons et al. } \\
(83)\end{array}$ & 1 & 12 months & $100 \%$ & Nil \\
\hline $\begin{array}{l}\text { Miller et al. } \\
(84)\end{array}$ & 6 & 10 months & $83 \%$ & Nil \\
\hline $\begin{array}{l}\text { Bartsch } \\
\text { et al. }(82)\end{array}$ & 1 & 15 month & $100 \%$ & Nil \\
\hline $\begin{array}{l}\text { Leone et al. } \\
(81)\end{array}$ & 1 & 10 month & $100 \%$ & Nil \\
\hline
\end{tabular}




\begin{tabular}{|l|l|l|l|l|}
\hline TOTAL & 9 & 12 months & $96 \%$ & \\
\hline
\end{tabular}

DBS, deep brain stimulation; SUNA, short-lasting unilateral neuralgiform headache attacks with autonomic features; SUNCT, short-lasting unilateral neuralgiform headache attacks with conjunctival injection and tearing

Table 6: Available evidence from published case series for ventral tegmental area deep brain stimulation in primary TACs 


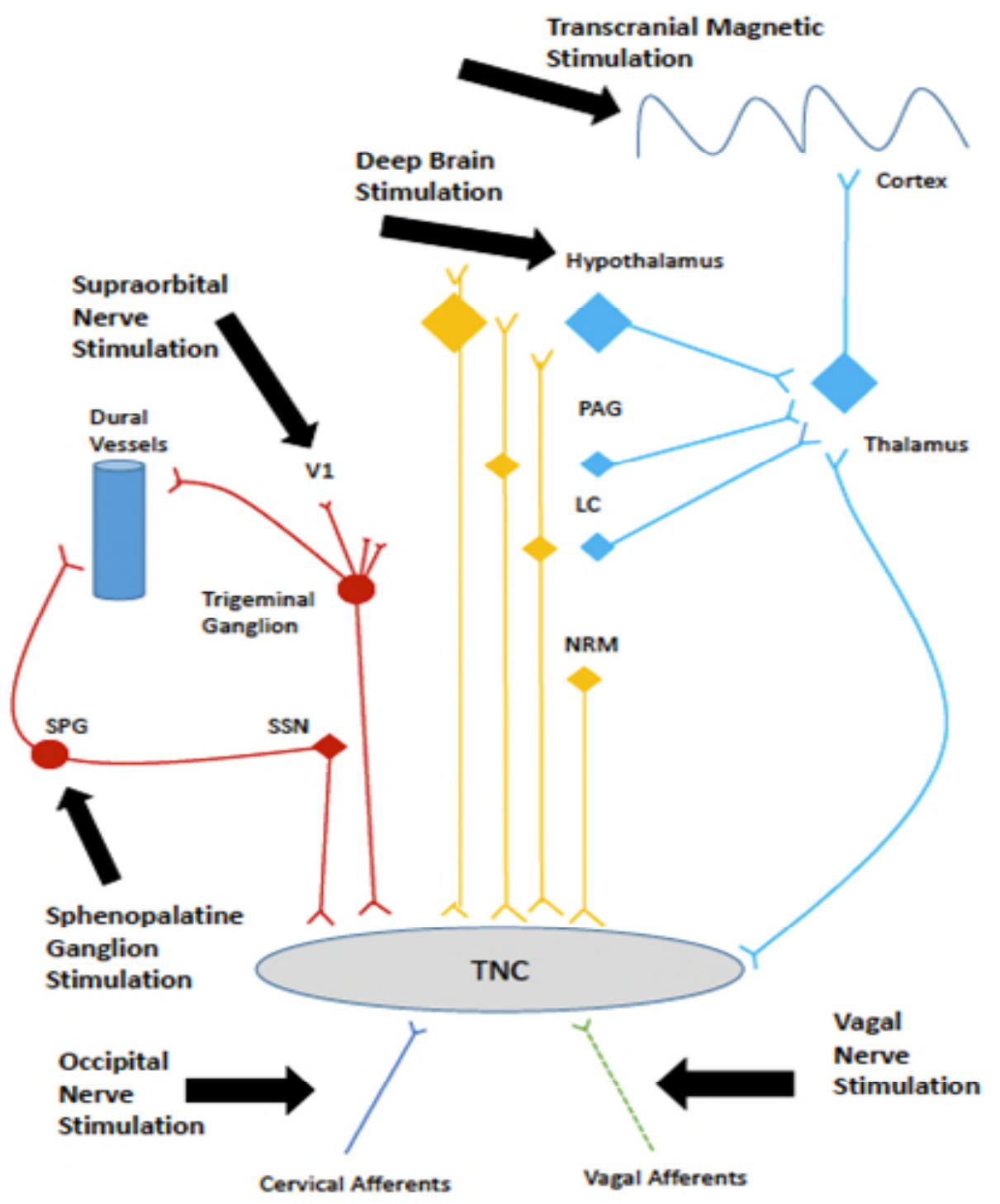

--- Vagal nerve afferents feed into the TNC via the nucleus tractus solitarisand the locus coerueus

LC, Locus ceruleus; NRM, Nucleus raphe magnus;; PAG, Periaqueductal gray; SPG, Sphenopalatine ganglion; ; SSN, superior salivatory nucleus; TNC, Trigeminal nucleus caudalis; V1, First branch of the trigeminal nerve

Figure 1: Schematic of headache pain pathways and the targets for neurostimulation 